University of Nebraska - Lincoln DigitalCommons@University of Nebraska - Lincoln

USGS Staff -- Published Research

US Geological Survey

4-2015

\title{
Underpressure in Mesozoic and Paleozoic rock units in the Midcontinent of the United States
}

Philip H. Nelson

US Geological Survey, Denver, Colorado, pnelson@usgs.gov

Nicholas J. Gianoutsos

US Geological Survey, Denver, Colorado, ngianoutsos@usgs.gov

Ronald M. Drake

US Geological Survey, Denver, Colorado, rmdrake@usgs.gov

Follow this and additional works at: http:/ / digitalcommons.unl.edu/usgsstaffpub

Nelson, Philip H.; Gianoutsos, Nicholas J.; and Drake, Ronald M., "Underpressure in Mesozoic and Paleozoic rock units in the Midcontinent of the United States" (2015). USGS Staff -- Published Research. 867.

http:// digitalcommons.unl.edu/usgsstaffpub/867

This Article is brought to you for free and open access by the US Geological Survey at DigitalCommons@University of Nebraska - Lincoln. It has been accepted for inclusion in USGS Staff -- Published Research by an authorized administrator of DigitalCommons@University of Nebraska - Lincoln. 


\section{Underpressure in Mesozoic and Paleozoic rock units in the}

\section{Midcontinent of the United}

\section{States}

\section{Philip H. Nelson, Nicholas J. Gianoutsos, and Ronald M. Drake II}

\section{ABSTRACT}

Potentiometric surfaces for Paleozoic strata, based on water well levels and selected drill-stem tests, reveal the control on hydraulic head exerted by outcrops in eastern Kansas and Oklahoma. From outcrop in the east, the westward climb of hydraulic head is much less than that of the land surface, with heads falling so far below land surface that the pressure:depth ratio in eastern Colorado is less than $5.7 \mathrm{kPa} / \mathrm{m}(0.25 \mathrm{psi} / \mathrm{ft})$. Permian evaporites separate the Paleozoic hydrogeologic units from a Lower Cretaceous (Dakota Group) aquifer, and a highly saline brine plume pervading Paleozoic units in central Kansas and Oklahoma is attributed to dissolution of Permian halite. Underpressure also exists in the Lower Cretaceous hydrogeologic unit in the Denver Basin, which is hydrologically separate from the Paleozoic units. The data used to construct the seven potentiometric surfaces were also used to construct seven maps of pressure:depth ratio. These latter maps are a function of the differences among hydraulic head, landsurface elevation, and formation elevation. As a consequence, maps of pressure:depth ratio reflect the interplay of three topologies that evolved independently with time. As underpressure developed, gas migrated in response to the changing pressure regime, most notably filling the Hugoton gas field in southwestern Kansas. The timing of underpressure development was determined by the timing of outcrop exposure and tilting of the Great Plains. Explorationists in western Kansas and eastern Colorado should not be surprised if a reservoir is underpressured; rather, they should be surprised if it is not.

\footnotetext{
Published by the American Association of Petroleum Geologists. (2)2015 U.S. Geological Survey. All rights reserved. Green Open Access. This paper is published under the terms of the CC-BY license.

Manuscript received September 12, 2014; provisional acceptance December 15, 2014; revised manuscript received March 16, 2015; final acceptance April 17, 2015.
}

DOI: 10.1306/04171514169

\section{AUTHORS}

PhILIP H. NeLSON US Geological Survey, Denver, Colorado; pnelson@usgs.gov

Philip H. Nelson received his B.S. and Ph.D. degrees in geophysics at the Massachusetts Institute of Technology in 1962 and 1967. He has held research positions in mineral exploration with Kennecott Exploration Services, radioactive waste storage with Lawrence Berkeley Laboratory, and oil and gas production with Sohio Petroleum Company, and is presently a member of the Central Energy Resources Science Center of the US Geological Survey in Denver, which provides domestic and worldwide assessments of undiscovered oil and gas. His current research interests are in the characteristics of tight gas resources and the pressure regimes of sedimentary basins.

NiCHOLAS J. GIANOUTSOS US Geological Survey, Denver, Colorado; ngianoutsos@ usgs.gov

Nicholas J. Gianoutsos is a physical scientist with the Central Energy Resources Science Center of the US Geological Survey. He earned his M.S. in computer science from Texas Tech University, and a B.S. in computer science from West Texas A\&M University. Before joining the Survey, he worked as a hydrographer on a NOAA research vessel mapping the bathymetry of the ocean floor and served as a park ranger in Denali National Park. His current research interests include pressure regimes in sedimentary basins, carbon sequestration, geographic information systems, and remote sensing.

RONALD M. DRAKE II US Geological Survey, Denver, Colorado; rmdrake@usgs.gov

Ronald M. Drake II is an assessment geologist in the Central Energy Resources Science Center of the US Geological Survey. He has a B.S. degree in geology (1992) from the University of Kansas, and a professional M.S. degree in exploration geosciences (2003) from the Colorado School of Mines. His background includes geologic mapping on the Yucca Mountain Project in Nevada (1993-2010) and geologic carbon sequestration assessments with the US 
Geological Survey (2010-2014). He is a member of AAPG and GSA.

\section{ACKNOWLEDGEMENTS}

We have benefitted from conversations with visitors to our posters at annual meetings of the Geological Society of America and AAPG and with numerous individuals, including Debra Higley and Larry Anna of the US Geological Survey, Pat Jackson of Comet Ridge Resources, Ray Sorenson of Tulsa, Oklahoma, and Jim Puckette of Oklahoma State University.

\section{INTRODUCTION}

Oil and gas wells drilled beneath the high plains of western Kansas and eastern Colorado encounter pressures less than hydrostatic, with pressure:depth ratios less than a freshwater gradient of $9.8 \mathrm{kPa} / \mathrm{m}(0.433 \mathrm{psi} / \mathrm{ft})$. This condition is referred to in the oil and gas industry as underpressure, and its presence affects several aspects of hydrocarbon discovery and recovery. The very existence of a given hydrocarbon accumulation may be due to late-stage expansion of gas responding to a decrease in aquifer pressure, and of course, the amount of gas present is a function of reservoir pressure. If mud weights are not adjusted, the normal pressure of drilling mud can mask indicators of the presence of oil or gas in underpressured reservoirs. Flowback of stimulation fluids and production rates are adversely affected by underpressure. Finally, underpressure affects the state of stress in the rock mass, is conducive to the disposal of wastewater, and must be considered in the design of systems to sequester supercritical carbon dioxide, should such projects become feasible.

The widespread occurrence of underpressure in the Midcontinent has been recognized by regional hydrologists who found that the potentiometric surfaces of Paleozoic and Mesozoic sequences lie well below surface elevation (Belitz and Bredehoeft, 1988; Jorgensen et al., 1993). For example, in eastern Colorado, western Nebraska, and northwestern Kansas, the potentiometric surface of the Maha Aquifer, equivalent in part to the Lower Cretaceous Dakota Group, lies 152-762 m (500-2500 ft) below the water table in shallow aquifers (Helgesen et al., 1993, their figure 26). Oil and gas accumulations are buoyantly supported by formations sufficiently permeable to be grouped together and considered as regional aquifers. Gas-dominated volumes of pore space occur in the deep parts of the Denver and Anadarko Basins but are not considered here.

In their study of the Denver Basin, Belitz and Bredehoeft (1988) provided the groundwork for understanding regional underpressured systems and clarified their controls, including an ultimate tie to outcrop. Expanded studies of the Midcontinent further demonstrated the large extent of the system and the need for regional studies to understand the complete hydrological system (Helgesen et al., 1993; Jorgensen et al., 1993). Our previous study sought to unravel the mix of overpressured conditions in the deep Anadarko Basin of Oklahoma with the normally pressured and underpressured conditions found on the northern and western flanks of the basin (Nelson and Gianoutsos, 2014a). Sorenson (2005) provided key insights on the expansion of gas into the present-day Hugoton gas field of southwestern Kansas, an expansion that occurred concurrently with the development of regional 


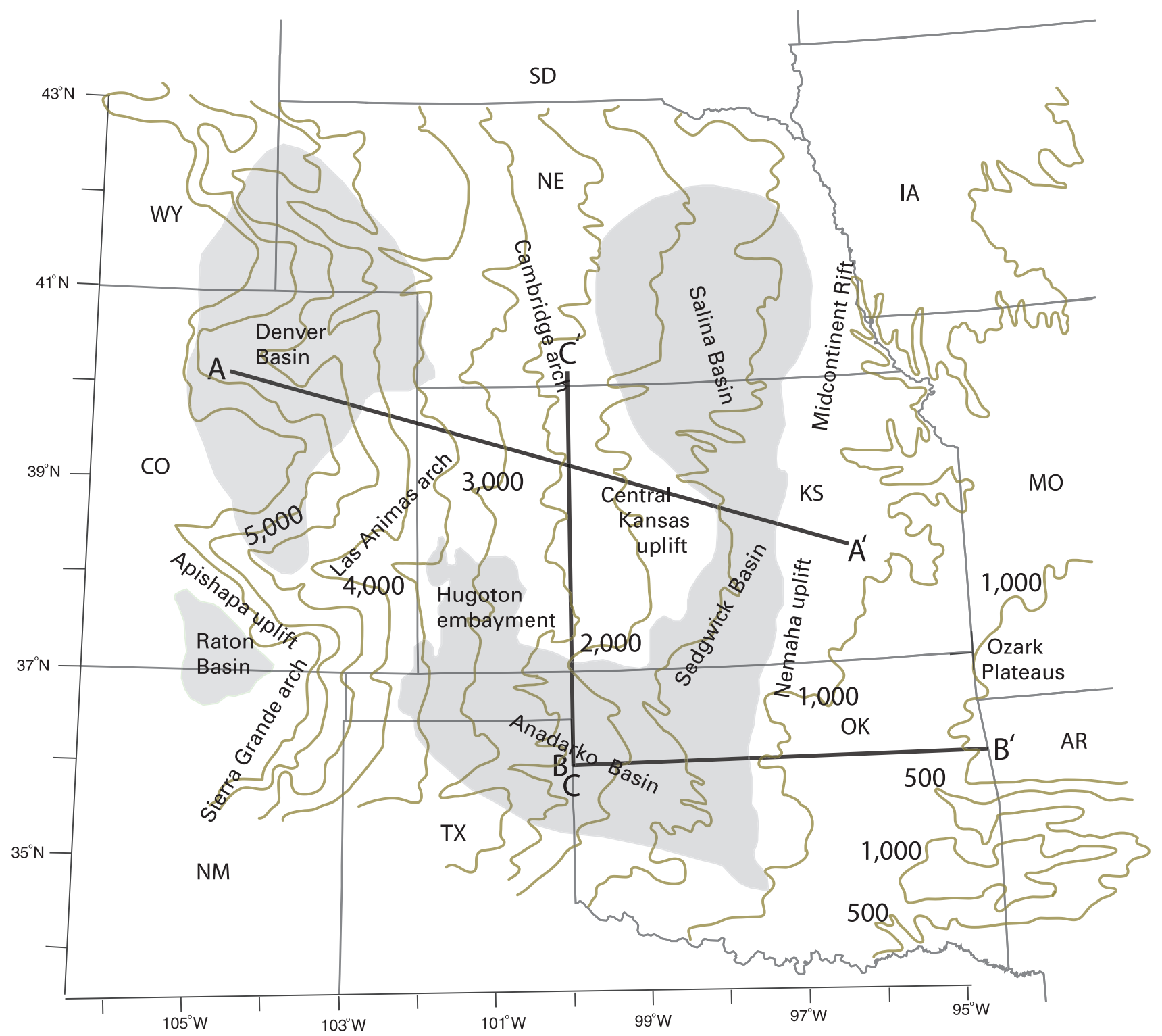

Figure 1. Map of Midcontinent study area showing the major structural features and contours of surface elevation, in feet. Line $A A^{\prime}$ shows location of geologic section of Figure 3; lines $\mathrm{BB}^{\prime}$ and $\mathrm{CC}^{\prime}$ refer to Figures 8 and 9 . The outlines of prominent structural features are based on Sims (1985), courtesy of US Geological Survey. Contour interval $=152 \mathrm{~m}$ (500 ft).

underpressure. These studies reveal the interdependence of petroleum accumulations and regional hydrology, and also show the necessity of a regional perspective to understand the processes involved. The present study of the Midcontinent includes the Denver Basin and the Anadarko Basin (except its deeper part), and their flanks, which encompass all of Kansas and portions of adjoining states, with the exception of the Raton Basin (Figure 1).

Underpressure also exists in the Raton Basin of south-central Colorado (Nelson et al., 2013).
However, the Raton Basin is hydrologically isolated from the Midcontinent by the Sierra Grande arch and Apishapa uplift (Figure 1). With a similar stratigraphic section and a land surface rising westward over plunging strata that crop out on its eastern flank, the Raton Basin serves as a scaled-down analog of the much larger Midcontinent hydrological system.

This paper differs from previous studies by incorporating numerous pressure data from both drill-stem tests (DSTs) and water wells, resulting in better spatial control of potentiometric surfaces, and by 
presenting regional pressure and pressure:depth-ratio maps. The potentiometric maps demonstrate that underpressure in Pennsylvanian-Permian strata is a result of the equilibration of confined aquifer pressure with atmospheric pressure at exposed outcrops in eastern Kansas and Oklahoma. This claim is substantiated by the spatial coincidence of head contours, land-surface contours, and outcrop exposures. The extent of underpressure is shown on companion maps of the pressure:depth ratio. These latter maps differ substantially from their respective potentiometric surfaces, and we show that their complicated topologies are due to the interplay of the potentiometric surface with the land and formation elevation surfaces.

The description of a large, highly saline brine plume constitutes an important finding of this paper, because (1) its extent has been poorly documented, (2) it complicates the choice of density used to calculate potentiometric surfaces, (3) it complicates the interpretation of flow from potentiometric surfaces, and (4) it may constrain estimates of recharge. This section is followed by a description of the procedure used to define the potentiometric surfaces and their companion maps of pressure:depth ratio. This procedure solves the challenging problem of selecting a small subset of representative data from a large, noisy data set. Hydraulic head calculated in oil and gas wells is then combined with water levels in water wells to show the continuity of the potentiometric surfaces from reservoir depth to outcrop. The resulting potentiometric surfaces substantiate the claim of outcrop control on the pressure regime. Maps of pressure:depth ratios show the spatial variability of underpressure as well as its widespread presence. Finally, a description of the geologic factors that create and maintain underpressure illustrates how formation elevation, the presence of isolating layers, varying surface elevation, and outcrop exposure have evolved with time to create the present-day underpressured condition.

\section{GEOLOGIC AND HYDROLOGIC SETTING}

The surface topography of the Midcontinent reflects the regional uplift of the high plains, with elevations of 1520-1675 m (4987-5495 ft) in eastern Colorado, decreasing to less than $305 \mathrm{~m}(1000 \mathrm{ft})$ in eastern Kansas and Oklahoma (Figure 1). Surface elevations rise again in the southeastern part of the study area, where elevations of the Ozark Plateaus exceed $305 \mathrm{~m}(1000 \mathrm{ft})$. Westward deflections of contours reflect the eastward courses of rivers. The easternmost 305-m (1000-ft) contour marks the western edge of the Ozark Plateaus in southwestern Missouri and northwestern Arkansas. With the exceptions of these last two features, surface topography can be regarded for our purposes as a plane tilted upward to the west formed during Cenozoic time.

Our study area is bounded by the Ozark Plateaus on the east, the deep part of the Anadarko Basin on the south, and attenuation and shallowing of Paleozoic strata on the north (Figures 1,2). In the west, the study area includes the Cretaceous rocks of the Denver Basin and the Las Animas arch, but the Las Animas arch is the western limit of pressure data for Paleozoic rocks. Shaped by the deep Anadarko Basin of west-central Oklahoma, the subsurface topography forms a half-bowl in central and western Kansas that persists from Precambrian throughout the Pennsylvanian section (Figure 2; Merriam, 1963, his figures 111-115). Cross section $\mathrm{AA}^{\prime}$ (Figure 3) shows depositional variation with thickening and thinning of units and the structural features of the Denver Basin, Las Animas arch, central Kansas uplift, and Nemaha uplift. The central Kansas uplift is subtle but present east of the Colorado border. The section shows truncation and erosion of Pennsylvanian, Mississippian, Devonian, Silurian, and Ordovician rocks in the Las Animas arch, central Kansas uplift, and Nemaha uplift areas during the early Paleozoic. The Nemaha uplift is a prominent feature showing thinning of Pennsylvanian rocks over the uplift and truncation of lower Paleozoic strata against uplifted Precambrian rock. Cenozoic, Cretaceous, and Permian strata crop out across most of Kansas along the line of cross section.

In eastern Kansas and Oklahoma, Permian through Desmoinesian strata crop out in a series of north to northeast-trending bands, with older strata farther east and at lower elevations than younger strata (Figure 4). Farther east, Mississippian and older strata are exposed on the higher elevations of the Ozark Plateaus in southwestern Missouri. These broad exposures, believed to have developed during 


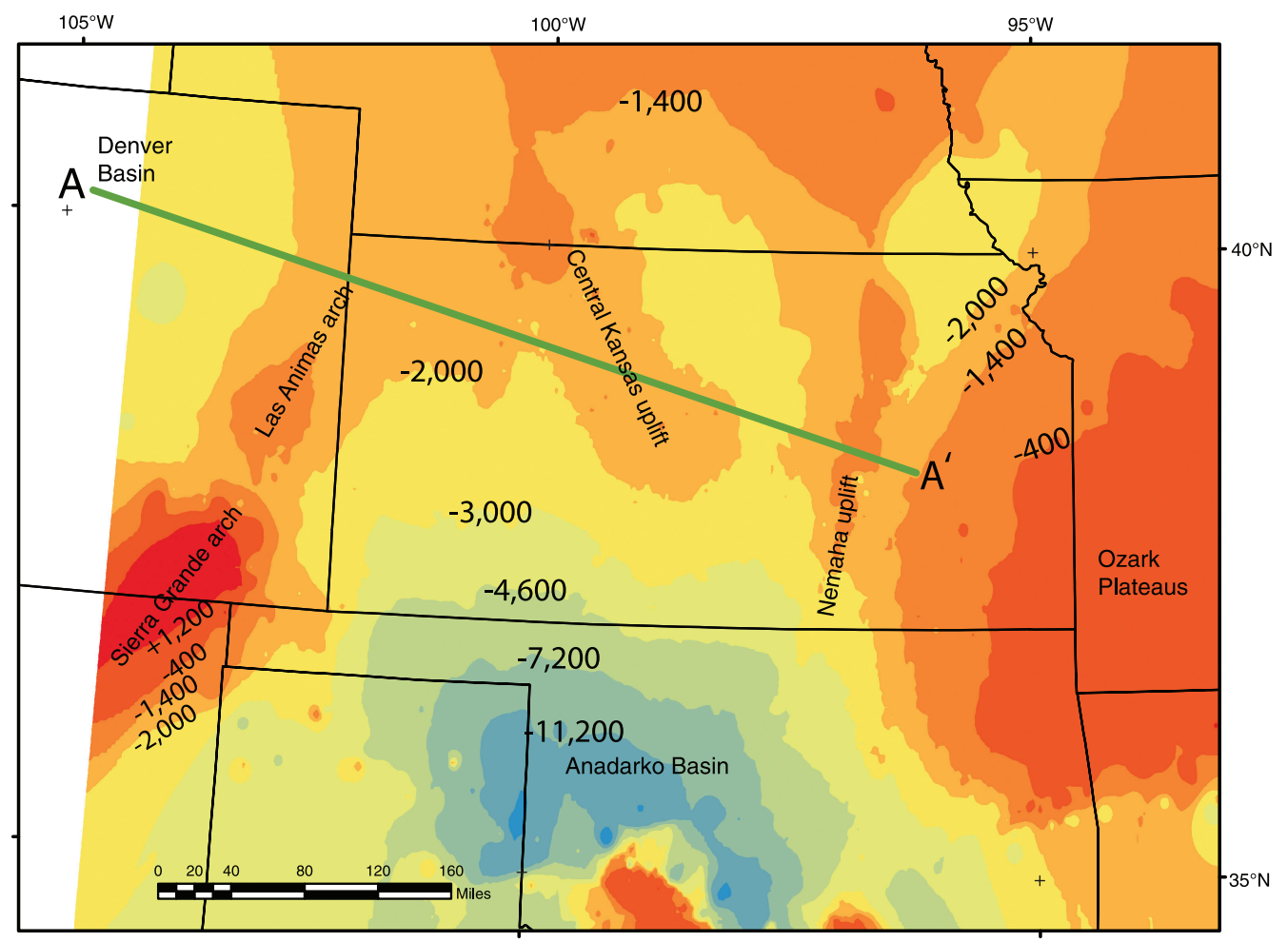

Figure 2. Structural map showing the top of Upper Cambrian and Lower Ordovician Arbuckle Group, with irregularly spaced contours of elevation in feet. Line $A A^{\prime}$ shows location of geologic section of Figure 3.

late Cenozoic time, serve as sources of groundwater and establish the reference to atmospheric pressure that governs the potentiometric response of their respective strata (Figures 3, 4).

Generation and migration of oil and gas northward from the Anadarko Basin of Oklahoma and Texas began during Mississippian and lasted through Permian time, and was tied to basin downwarping and increased sediment deposition (Higley, 2014a). The resulting widespread accumulations of oil and gas in eastern Colorado, western and central Kansas, and western and central Oklahoma are the source of pressure data for the Paleozoic potentiometric maps of this paper. Similarly, generation and migration of oil and gas from the Denver Basin during the Laramide orogeny resulted in petroleum accumulations, drilling for which furnished the pressure data for the Lower Cretaceous (Dakota Group) potentiometric surface.

Hydrocarbon generation in the Anadarko Basin created overpressured conditions that extended northward as far as the Oklahoma-Kansas border before retreating southward to the deep basin (Nelson and Gianoutsos, 2014a). It appears that overpressured strata in Oklahoma have blocked the migration of highly saline pore waters in north-central Oklahoma, as will be illustrated in this paper. Present-day overpressured areas form the southern edge of the potentiometric maps of this paper, because pressure cannot be readily converted to hydrostatic head in which strata are charged with gas and buoyancy has been lost.

This study maps the potentiometric surfaces and pressure:depth ratios for the seven hydrogeologic units depicted on the stratigraphic column of Figure 5: (1) Cambrian-Ordovician-Silurian, (2) Mississippian, (3) Desmoinesian, (4) Missourian, (5) Virgilian, (6) Permian (Wolfcampian), and (7) Lower Cretaceous (Dakota Group). Previous regional studies of Midcontinent hydrology used somewhat different hydrogeologic divisions, as shown in Figure 5. Most importantly, in this study, Pennsylvanian and Permian sequences are mapped as four hydrogeologic unitsDesmoinesian, Missourian, Virgilian, and Permian (Wolfcampian)—whereas previous studies considered the Pennsylvanian and Permian either as a single aquifer or a single semiconfining unit. These four Pennsylvanian and Permian hydrogeologic units share an important feature in common: All crop out in eastern Kansas and Oklahoma in north-trending bands (Figure 4). 


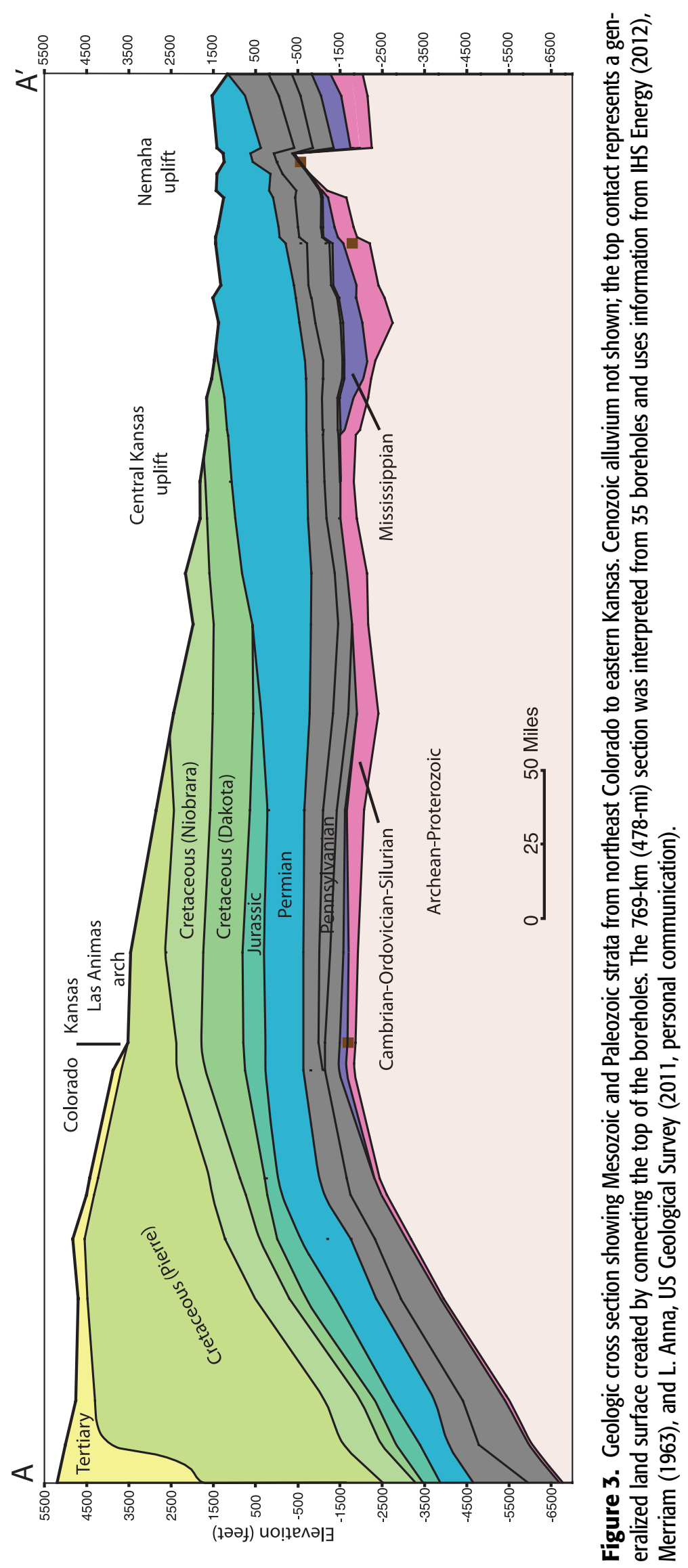




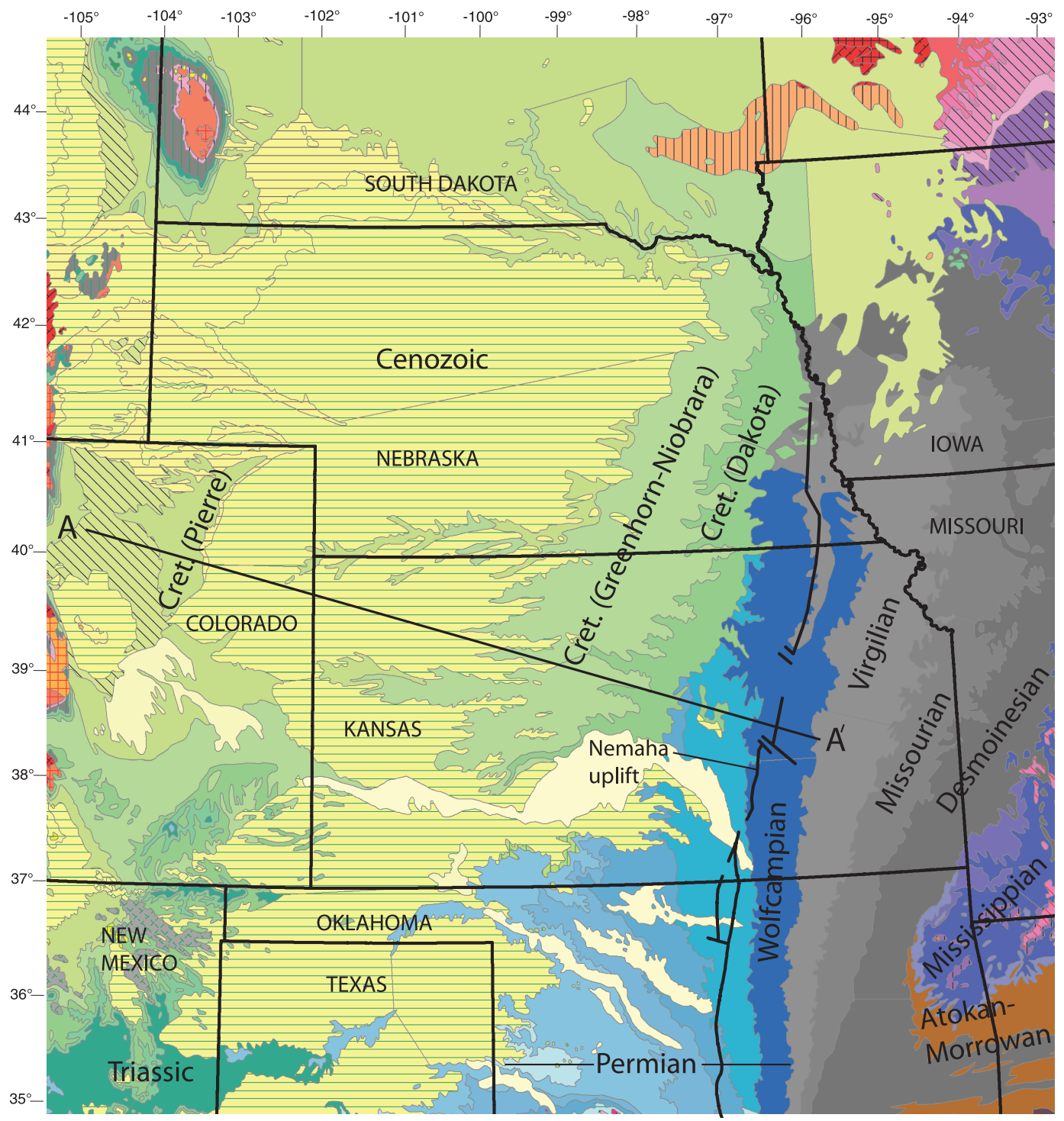

Figure 4. Geologic map of the Midcontinent, showing outcrops of Paleozoic, Mesozoic, and Cenozoic strata. The Nemaha uplift coincides with lower Permian outcrops. Base map modified from Schruben et al. (1997), courtesy of US Geological Survey. Cret. $=$ Cretaceous.

The Cambrian-Ordovician-Silurian and Mississippian hydrogeologic units of the present study are similar to the lower and upper aquifer units of the Western Interior Plains and Ozark Plateaus aquifer system of Jorgensen et al. (1993), as shown in Figure 5. As noted by Jorgensen et al. (1993), these two regional hydrologic systems - the Western Interior Plains and Ozark Plateaus aquifer systems - meet in a broad topographic low in eastern Oklahoma and Kansas. In this paper, the join between two large-scale aquifer systems appears as a potentiometric low in eastern Oklahoma.

The important role of low-permeability layers, such as shale or evaporites, in isolating confined aquifers from land surface or shallower hydrologic systems was underscored by Belitz and Bredehoeft (1988). The Upper Cretaceous Pierre Shale and underlying shales isolate the Dakota Group aquifer from the surface (Figures 3, 5). Similarly, the Permian mudstones and evaporites of the Sumner, Nippewalla, and Whitehorse Groups (Figure 5) isolate the Lower Permian and Pennsylvanian strata from the Dakota Group aquifer. Dissolution of halite in the Permian evaporitic sequence has produced a highly saline plume within the Midcontinent, and because the resulting variations in fluid density complicate the computation of hydraulic head, the saline plume is discussed in the next section. 
Figure 5. Stratigraphic column, showing the seven hydrogeologic units defined in this study and the units defined in hydrologic studies of Jorgensen et al. (1993) and Belitz and Bredehoeft (1988). Prominent lithostratigraphic units with an asterisk are sources of drill-stem tests, and those with a pound sign are considered impermeable isolating units. Maps of potentiometric surfaces based on subsurface data are indicated with $M$. Nomenclature for series and prominent lithostratigraphic units taken from Merriam (1963), Belitz and Bredehoeft (1988), and IHS Energy (2012).

\begin{tabular}{|c|c|c|c|c|c|c|}
\hline$\frac{\frac{\varepsilon}{Q}}{n}$ & $\begin{array}{l}\text { Series or } \\
\text { Stages }\end{array}$ & $\begin{array}{l}\text { Prominent Lithostratigraphic } \\
\text { Units }\end{array}$ & $\begin{array}{l}\text { Hydrogeologic } \\
\text { Units, this study }\end{array}$ & \multicolumn{2}{|c|}{$\begin{array}{l}\text { Geohydrologic } \\
\text { Units of Jorgenson } \\
\text { et al. (1993) }\end{array}$} & $\begin{array}{l}\text { Hydrostratigraphic } \\
\text { Units of Belitz and } \\
\text { Bredehoeft (1988) }\end{array}$ \\
\hline 离 & & Ogallala Formation & & \multicolumn{2}{|c|}{ High Plains aquifer } & \\
\hline \multirow{4}{*}{ 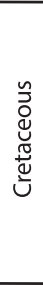 } & Upper & \begin{tabular}{|l|} 
Pierre Shale\# \\
Niobrara Formation\# \\
Carlile Shale\# \\
Greenhorn Limestone\# \\
Graneros Shale\#
\end{tabular} & & \multicolumn{2}{|c|}{$\begin{array}{l}\text { Great Plains } \\
\text { confining system }\end{array}$} & $\begin{array}{l}\text { Cretaceous } \\
\text { shales }\end{array}$ \\
\hline & \multirow{3}{*}{ Lower } & \multirow{3}{*}{ Dakota D and I sandstones* } & \multirow{3}{*}{$\begin{array}{l}\text { Lower } \\
\text { Cretaceous } \quad M \\
\text { (Dakota Gp.) }\end{array}$} & Maha aquifer & & \multirow{3}{*}{$\begin{array}{l}\text { Dakota and } \\
\text { basal Cretaceous } \\
\text { sandstones } \\
\qquad M\end{array}$} \\
\hline & & & & \multirow{2}{*}{\multicolumn{2}{|c|}{\begin{tabular}{|l|l}
$\begin{array}{l}\text { Apishapa } \\
\text { confining unit }\end{array}$ & $\begin{array}{l}\text { Plains } \\
\text { aquifer } \\
\text { system }\end{array}$ \\
\cline { 1 - 1 } Apishapa aq. & $\mathrm{M}$ \\
\end{tabular}}} & \\
\hline & & & & & & \\
\hline$\frac{u}{n}$ & & Morrison Formation & & \multirow{14}{*}{\multicolumn{2}{|c|}{$\begin{array}{l}\text { Western } \\
\text { Interior } \\
\text { Plains } \\
\text { confining } \\
\text { system }\end{array}$}} & \multirow{3}{*}{$\begin{array}{l}\text { Jurassic - } \\
\text { Triassic }\end{array}$} \\
\hline$\stackrel{\frac{\pi}{2}}{\beth}$ & & & & & & \\
\hline$\frac{u}{n}$ & & Dockum Group & & & & \\
\hline$F$ & & & & & & \multirow{4}{*}{$\begin{array}{l}\text { Triassic - } \\
\text { Permian }\end{array}$} \\
\hline \multirow{4}{*}{$\frac{\frac{c}{0}}{\frac{\pi}{2}}$} & Ochoan & 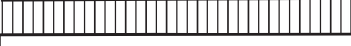 & & & & \\
\hline & Guadalupian & Whitehorse Group\# & & & & \\
\hline & Leonardian & Sumner Group\# & & & & \\
\hline & Wolfcampian & $\begin{array}{l}\text { Chase Group* } \\
\text { Council Grove Group* } \\
\text { Admire Group* }\end{array}$ & $\begin{array}{l}\text { Permian } \\
\text { (Wolfcampian) }\end{array}$ & & & \multirow{6}{*}{$\begin{array}{l}\text { Permian - } \\
\text { Pennsylvanian } \\
\qquad \mathrm{M}\end{array}$} \\
\hline \multirow{5}{*}{ 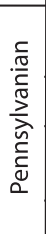 } & Virgilian & $\begin{array}{l}\text { Wabaunsee Group** } \\
\text { Shawnee Group** } \\
\text { Douglas Group* } \\
\end{array}$ & Virgilian $\quad M$ & & & \\
\hline & Missourian & $\begin{array}{l}\text { Lansing Group* } \\
\text { Kansas City Group* }\end{array}$ & Missourian $\quad M$ & & & \\
\hline & Desmoinesian & $\begin{array}{l}\text { Marmaton Group** } \\
\text { Cherokee Group* }\end{array}$ & Desmoinesian $\mathrm{M}$ & & & \\
\hline & Atokan & & & & & \\
\hline & Morrowan & & & & & \\
\hline$\frac{\sqrt{0}}{\frac{\pi}{2}}$ & Chesterian & Mississippian, undivided & & & & \multirow{10}{*}{$\begin{array}{r}\text { Pre-Pennsylvanian } \\
M\end{array}$} \\
\hline$\frac{0}{n}$ & Meramecian & St. Louis Limestone* ${ }^{*}$ & Mississippian $\quad M$ & Upper & \multirow{7}{*}{$\begin{array}{l}\text { Western } \\
\text { Interior } \\
\text { Plains } \\
\text { and } \\
\text { Ozark } \\
\text { Plateaus } \\
\text { aquifer } \\
\text { systems }\end{array}$} & \\
\hline$\stackrel{\mathscr{n}}{\Sigma}$ & $\begin{array}{l}\text { Osagean } \\
\text { Kinderhookian }\end{array}$ & $\begin{array}{l}\text { Mississippian chat } \\
\text { Kinderhook shale* }\end{array}$ & & $\begin{array}{l}\text { aquifer } M \\
\text { unit }\end{array}$ & & \\
\hline ठें & & Woodford Shale\# & & $\begin{array}{l}\text { Confining } \\
\text { unit }\end{array}$ & & \\
\hline 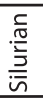 & & Hunton Group* & \multirow{5}{*}{$\begin{array}{l}\text { Cambrian- } \\
\text { Ordovician- } \quad M \\
\text { Silurian }\end{array}$} & \begin{tabular}{|l|}
$\begin{array}{l}\text { Lower } \\
\text { aquifer } M \\
\text { unit }\end{array}$ \\
\end{tabular} & & \\
\hline \multirow{3}{*}{$\begin{array}{l}\frac{1}{0} \\
\frac{0}{2} \\
\frac{0}{2} \\
\frac{0}{0} \\
0\end{array}$} & Upper & Viola Limestone* & & & & \\
\hline & Middle & Simpson Group* & & & & \\
\hline & Lower & Arbuckle Group* & & & & \\
\hline 官 & Upper & Reagan Sandstone* & & \multirow{2}{*}{\multicolumn{2}{|c|}{$\begin{array}{l}\text { Basement } \\
\text { confining } \\
\text { unit }\end{array}$}} & \\
\hline$\psi$ & & & & & & \\
\hline
\end{tabular}

\section{THE HIGH-SALINITY PLUME}

In this section, we document the presence of a plume of highly saline pore water in Paleozoic rock units, attributed to the dissolution of Permian salt beds.

Salinity data for waters in Mississippian formations are shown in Figure 6, based on 650 samples extracted from a database of water produced from oil and gas wells (Breit, 2002). All samples in the database for the mapped area were used, regardless of the sampling method used. The data are grouped into eight ranges that correspond to increments of $0.23 \mathrm{kPa} / \mathrm{m}(0.01 \mathrm{psi} / \mathrm{ft})$ (Table 1$)$. The map reveals a high-salinity (total dissolved solids [TDS] greater 


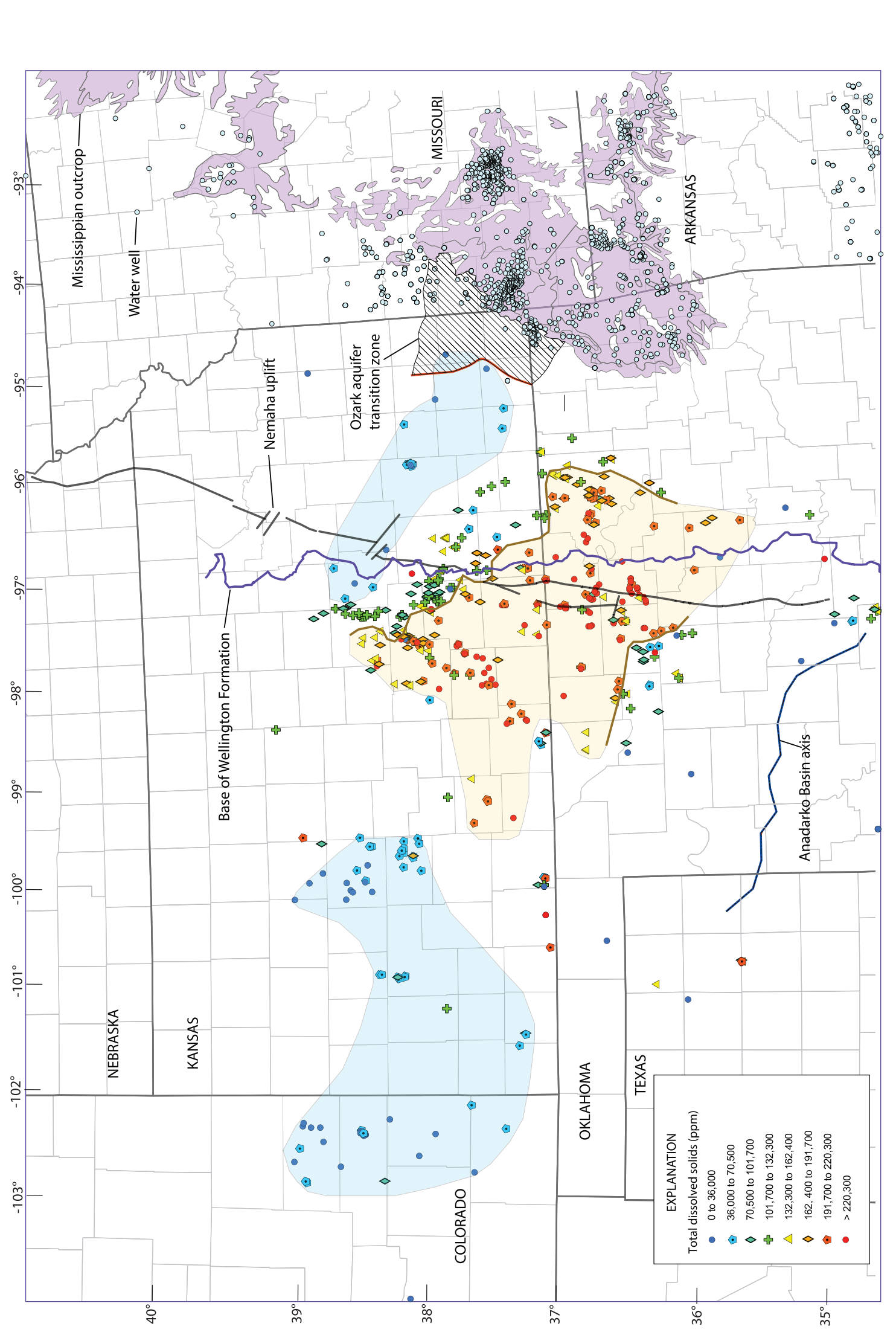

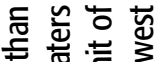

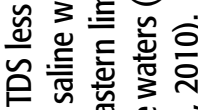

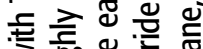

늘 흘 흔 흔

인

乞

ठे

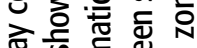

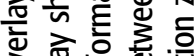

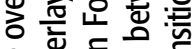

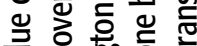

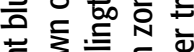

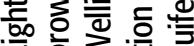

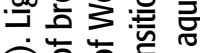

สิ응 든

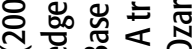

는

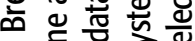

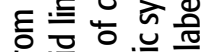

능 등응

흥 응

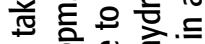

蚛 응

잉음

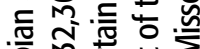

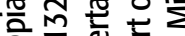

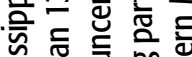

语宁

$\sum \bar{c}$

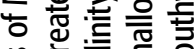

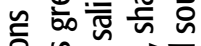

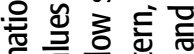

통응

흔

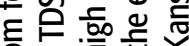

을 들

는

뜬은

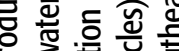

흔 呟 흔

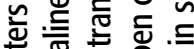

흄ㅎㅎㅇ

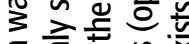

들

음 些 은

행 음 등

음 흥흥

हो 흔

ऽ등.

比文交

高

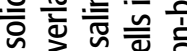

प्ठ

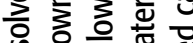

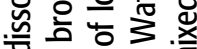

를

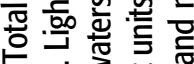

๑

음율

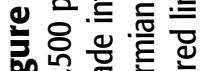

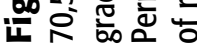


Table 1. Offset of Hydraulic Head $\mathrm{H}$ ( $\mathrm{ft}$ ) as a Function of Pressure and Brine Density, Relative to $\mathrm{H}$ Computed for a Density of $10.5 \mathrm{kPa} / \mathrm{m}(0.465 \mathrm{psi} / \mathrm{ft})^{*}$

\begin{tabular}{llccccccr}
\hline \multicolumn{7}{c}{ Brine Properties } \\
\hline Pgrd. (psi/ft) & 0.433 & 0.445 & 0.455 & 0.465 & 0.475 & 0.485 & 0.495 & 0.505 \\
Spec. gravity & 1 & 1.028 & 1.051 & 1.074 & 1.097 & 1.120 & 1.143 & 1.166 \\
TDS (ppm) & 0 & 35,754 & 70,552 & 101,737 & 132,349 & 162,377 & 191,723 & 220,284 \\
\hline Pressure (psi) & \multicolumn{7}{c}{ Offset in Hydraulic Head H (ft) } \\
\hline 500 & 79 & 48 & 24 & 0 & -23 & -44 & -65 & -85 \\
1000 & 159 & 97 & 47 & 0 & -45 & -89 & -130 & -170 \\
1500 & 238 & 145 & 71 & 0 & -68 & -133 & -196 & -256 \\
2000 & 318 & 193 & 95 & 0 & -91 & -177 & -261 & -341 \\
2500 & 397 & 242 & 118 & 0 & -113 & -222 & -326 & -426 \\
3000 & 477 & 290 & 142 & 0 & -136 & -266 & -391 & -511 \\
3500 & 556 & 338 & 165 & 0 & -158 & -310 & -456 & -596 \\
\hline
\end{tabular}

*Top three rows show the equivalence among pressure gradient $\rho g$, specific gravity, and total dissolved solids (TDS). Equivalent TDS for sodium-chloride solutions taken from Wolf et al. (1973). Pgrd. = pressure gradient $\rho g$; psi/ft = pounds per square inch per foot; spec. gravity = specific gravity; ppm = parts per million.

than $132,300 \mathrm{ppm}$, roughly four times greater than the nominal salinity of seawater) area in southcentral Kansas and north-central Oklahoma that is bounded on the northeast and southwest by lower salinity data but, because of a lack of data, is open to the northwest and south. Two areas in western and eastern Kansas (shaded light blue in Figure 6) are comparatively low in salinity, although the upper bound of 70,500 ppm is roughly twice the nominal salinity of seawater, and a few samples in western Kansas exceed 70,500 ppm. The Mississippian high-salinity plume straddles both the Nemaha uplift and the base of the Wellington Formation (Figure 6). The Wellington Formation, of the Leonardian Sumner Group, is the lowermost of the Permian evaporite-bearing formations, and its base, shown in Figures 6 and 7, roughly marks the easternmost extent of Permian halite occurrences. The Hutchinson Salt Member of the Wellington Formation is the thickest and most widespread of the Permian salt units in Kansas (Merriam, 1963, p. 84), with an eastern dissolution front that is 5-15-km (3-9-mi) wide and extends $150 \mathrm{~km}$ (93 mi) north-south (Anderson et al., 1994; Watney et al., 2003).

The outline of the high-salinity Mississippian plume is combined in Figure 7 with outlines of high-salinity plumes from three other hydrogeologic units, also based on data from Breit (2002). All four outlines enclose TDS values greater than $132,300 \mathrm{ppm}$ in their respective rock units. The four shapes are roughly similar, straddling the Nemaha uplift and the outcrop of the base of the Wellington Formation, extending westward into southwestern Kansas and the Oklahoma panhandle, and displaying a southward extension that narrows south of latitude $36^{\circ}$ coinciding with the Nemaha uplift and the base of the Wellington Formation. The high-salinity plume is absent south of $36.5^{\circ}$ and west of $-97.5^{\circ}$. Lobes of high-salinity have migrated into an area once overpressured (labeled "paleopressure" in Figure 7) but have not occupied the area of present-day overpressure south of $36^{\circ} \mathrm{N}$. It appears that elevated pressure created with the generation and migration of hydrocarbons has blocked the downward migration of dense saline brine into the deep part of the Anadarko Basin.

In addition to the map view, the boundaries of high-salinity waters are projected onto cross sections $\mathrm{BB}^{\prime}$ and $\mathrm{CC}^{\prime}$ (Figures 8, 9). Because the boundaries of the saline plumes were drawn to encompass high-salinity ( $>132,300 \mathrm{ppm})$ points but were not extrapolated beyond them, the boundaries shown in Figures 7, 8, and 9 are regarded as 


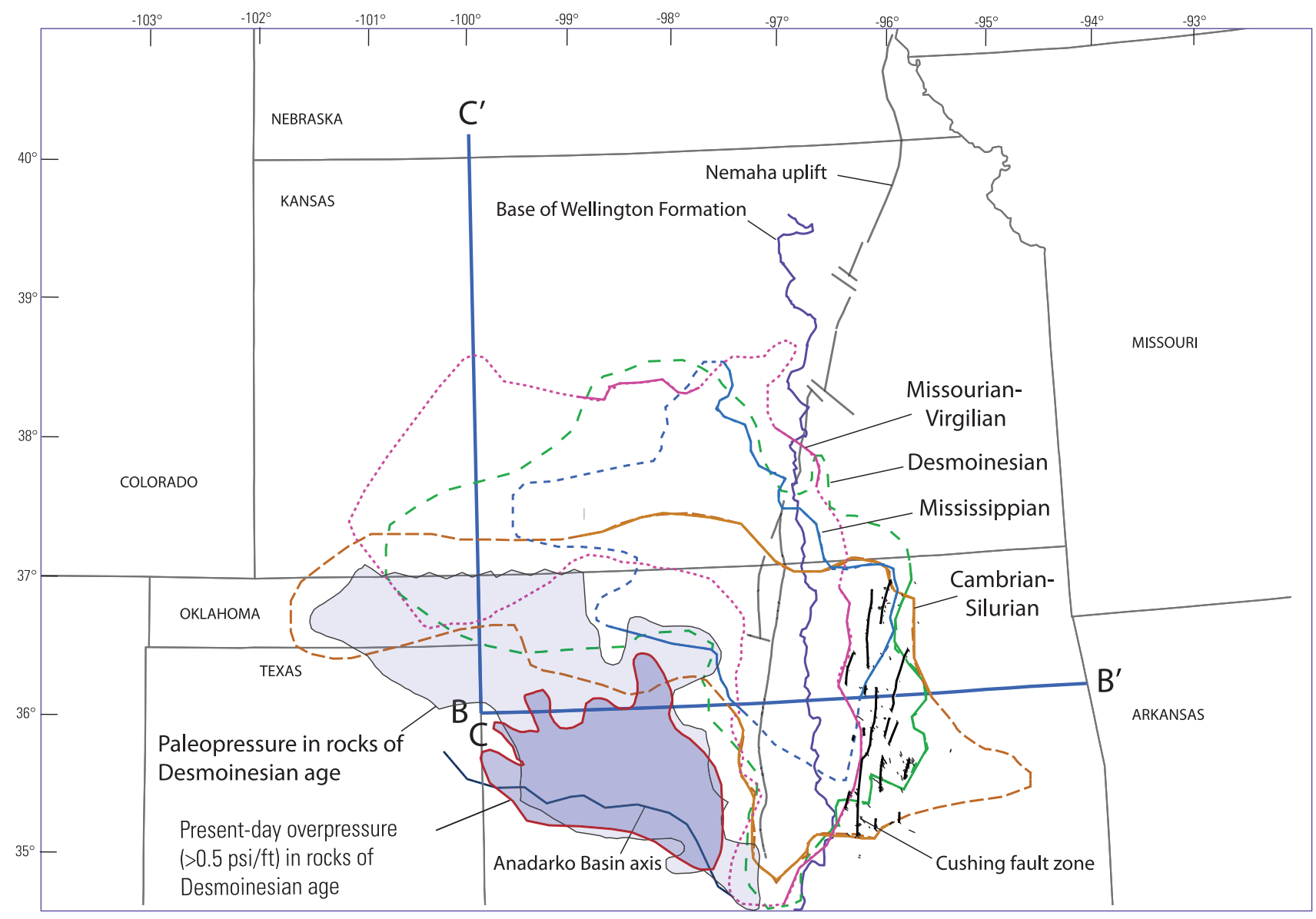

Figure 7. Outlines of highly saline (TDS $>132,000 \mathrm{ppm}$ ) formation waters in four hydrogeologic units. Outlines are solid where data show high-salinity values grading sharply into lower salinity values. Outlines are dashed where sparse data make the location of the boundary less certain. The high-salinity waters of all four hydrogeologic units straddle the Nemaha uplift. East of the Nemaha uplift in Oklahoma, north-trending lines connect short extensional faults from Miser (1954), collectively labeled here as the Cushing fault zone. Blue lines along $-100^{\circ} \mathrm{W}$ and $-36^{\circ} \mathrm{N}$ show locations of cross sections in Figures 8 and 9. Outlines of Desmoinesian paleopressure and present-day overpressure taken from Nelson and Gianoutsos (2014a), courtesy of US Geological Survey. TDS = total dissolved solids.

minimum extents, that is, additional data are likely to create an expansion of the boundaries rather than a contraction. The downward taper of the plume along longitude $100^{\circ} \mathrm{W}$ (Figure 9) is consistent with downward migration of highly saline brine from the Permian evaporites. However, the brine plume along latitude $36^{\circ} \mathrm{N}$ (Figure 8) is detached and offset from the Permian evaporites, suggesting that the plume has migrated eastward and downward.

The produced waters are chloride rich at all TDS levels, with the sample values distributed uniformly from 2440 to $265,000 \mathrm{ppm}$, and with fewer samples in the range from 265,000 to $306,000 \mathrm{ppm}$. Compared to chloride, bicarbonate and sulfate are negligible, with average concentrations of
190 and $670 \mathrm{ppm}$, respectively. Sodium is the dominant cation, roughly four times as abundant as calcium by weight and more than 20 times as abundant as magnesium. In summary, the formation waters are predominantly sodium chloride, ranging in salinity from less than one-tenth to nearly 10 times the salinity of seawater $(35,000 \mathrm{ppm})$. The general distribution of water with salinities of $35,000 \mathrm{ppm}$ and less was recently mapped by Osborn et al. (2013).

Where Permian strata crop out in western Oklahoma and adjoining parts of Kansas and Texas (Figure 4), salt dissolution is manifested by salt springs and seeps and by salt plains ranging in size from less than an acre to more than $155 \mathrm{~km}^{2}$ 
ì

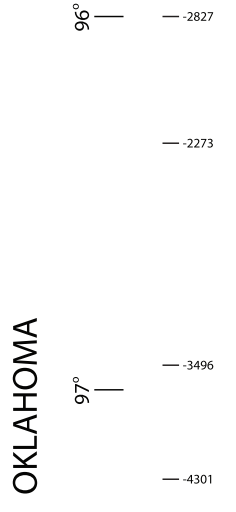

s-

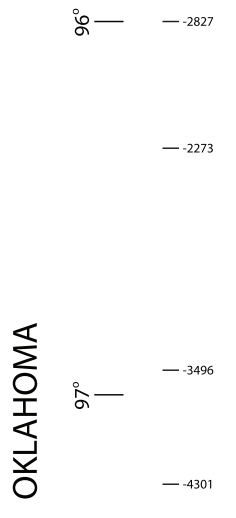

$-11475$

$\infty$

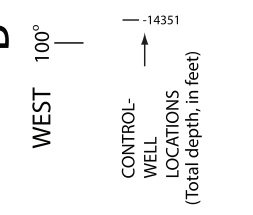

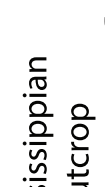
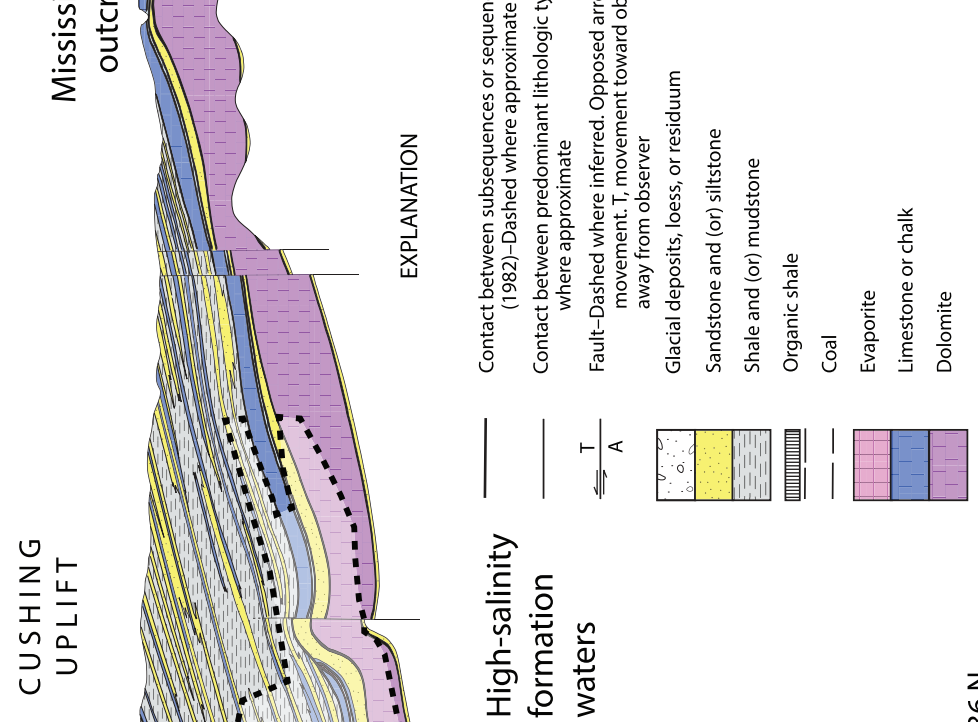

年

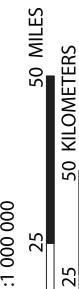

흔

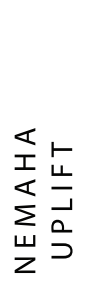

:
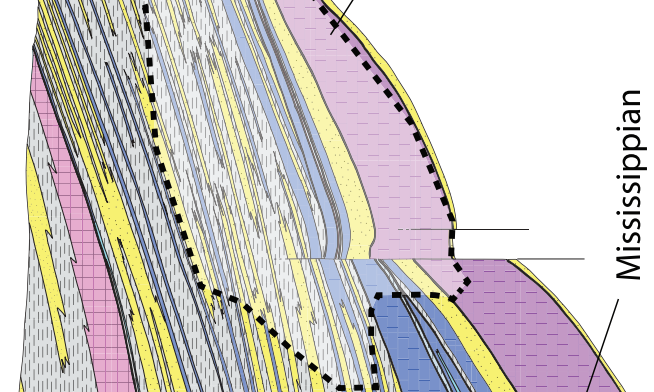

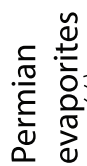
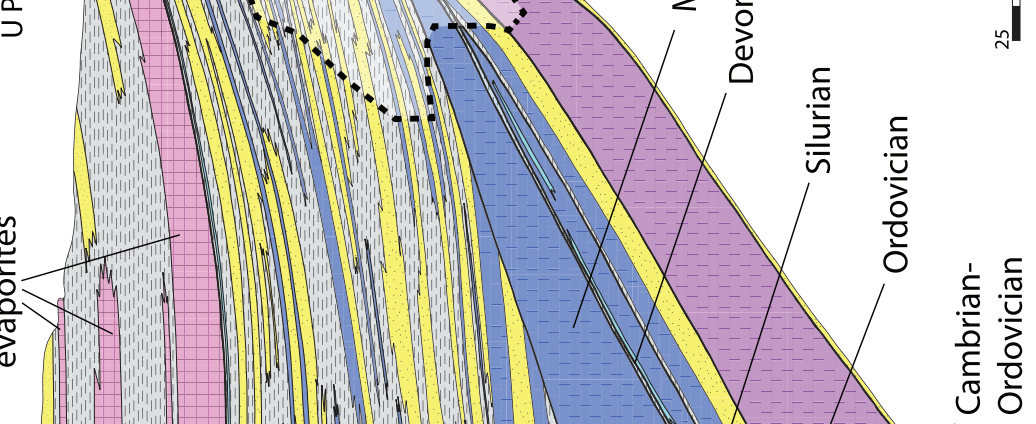

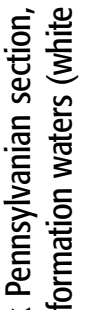

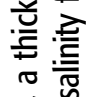

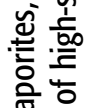

흥 흥

들 륭

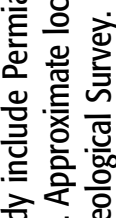

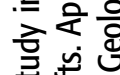

依言岁

흔

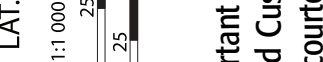

品焉

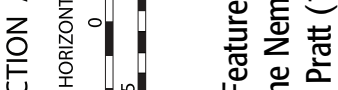

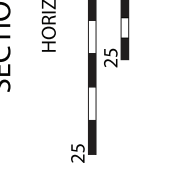

西

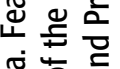

突㽞

蓄产衣

. 즐 을

至

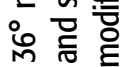

苋 它.

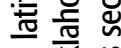

응

흠든

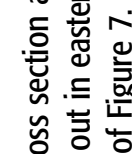

능응

至言

ญ 등

密意要

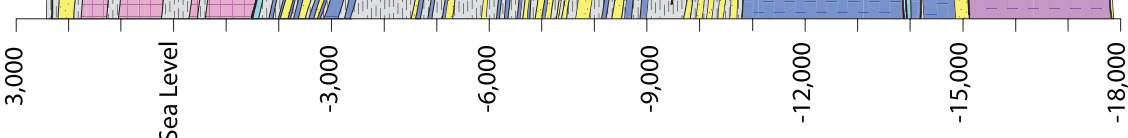

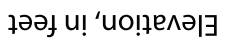

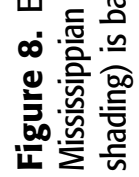




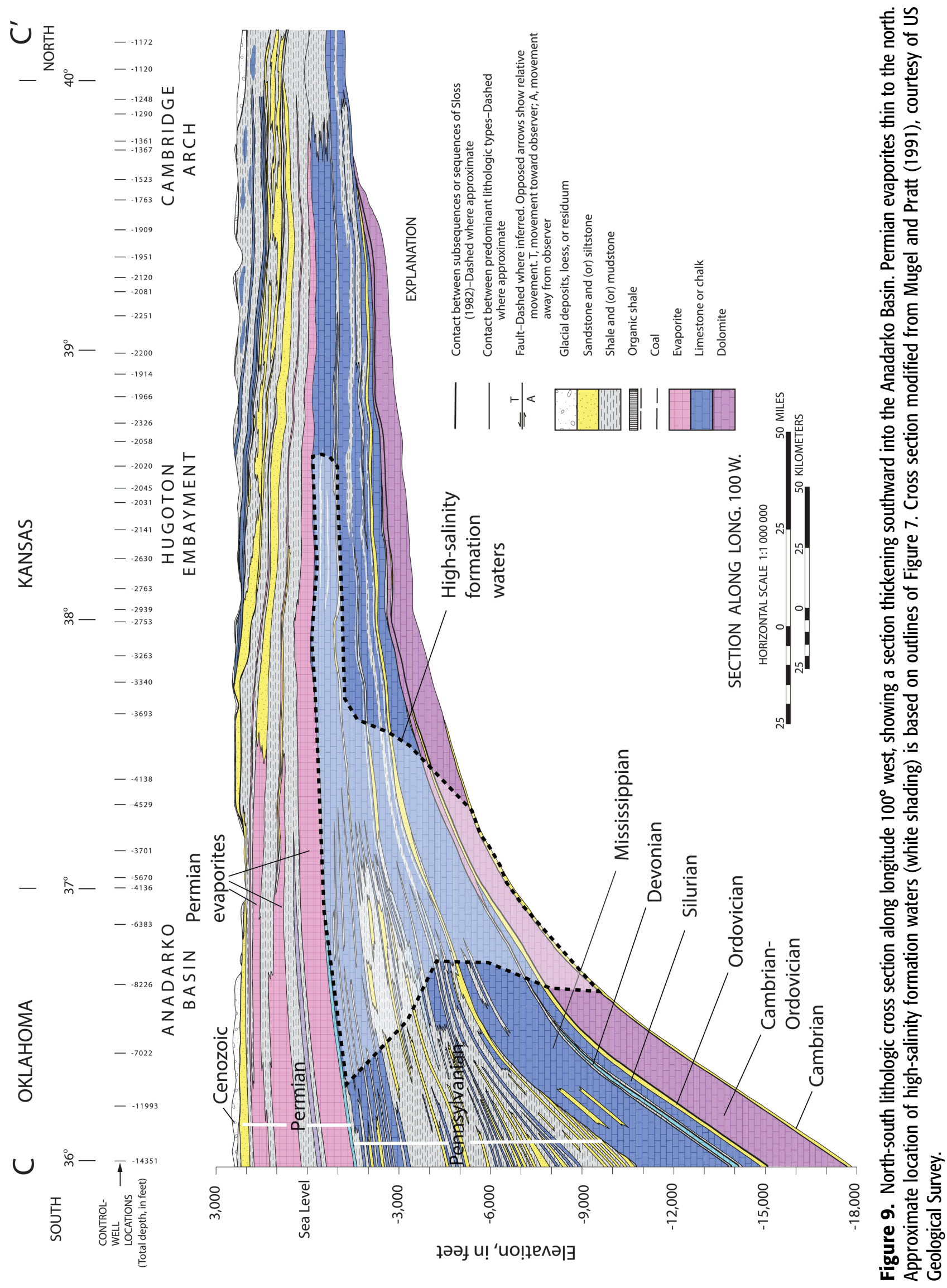

Nelson et al. 
(58 $\mathrm{mi}^{2}$ ). Ward (1963, p. 1) described the dissolution of halite from Permian strata

All the natural salt-contributing areas studied are within the outcrop area of rocks of Permian age. The Permian rocks, commonly termed red beds, are composed principally of red and gray gypsiferous shale, siltstone, sandstone, gypsum, anhydrite, and dolomite. Many of the formations contain halite in the subsurface. The halite occurs mostly as discontinuous lenses in shale, although some of the thicker, more massive beds are extensive. It underlies the entire region studied at depths ranging from

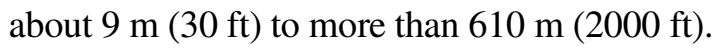
The salt and associated strata show evidence of extensive removal of salt through solution by ground water. Although the salt generally occurs in relatively impervious shale, small joints and fractures allow the passage of small quantities of water which dissolves the salt.

The composition of accessible groundwater across the northern tier of counties in Oklahoma can be examined for dissolution of evaporites. Calcium, magnesium sulfate waters with TDS between 2000 and $3000 \mathrm{ppm}$ are produced from water wells in an area in northwest Oklahoma (latitude $36.7^{\circ}$ to $37.0^{\circ}$, longitude $-98.6^{\circ}$ to $-99.8^{\circ}$ ) in which gypsum-bearing Permian formations comprise the bedrock (Morton, 1980). Several salt plains are located in this area. East of this area, from longitude $-98.6^{\circ}$ to the Oklahoma-Arkansas border, groundwater composition varies but with no obvious signature of gypsum or halite dissolution (Marcher and Bingham, 1971; Bingham and Bergman, 1980). It appears that high sodiumchloride waters are found in strata deeper than the Permian evaporites, but not shallower. Permian evaporites in much of the Midcontinent are a likely source of brine in Paleozoic strata because the dissolution of evaporites in the subsurface is recognized as one of the main processes in the creation of highly saline sodium chloride brines in the subsurface (Kharaka and Hanor, 2013).

The eastern low-salinity area grades into the Ozark aquifer transition zone (Figure 6) that separates the sodium-chloride waters to the west from bicarbonate waters sourced from the Ozark Plateaus to the east (Macfarlane, 2010). The aquifer system includes aquifers and confining units ranging in age from Cambrian to Mississippian (Figure 5). The western boundary of the transition zone (red line in Figure 6) is set at a TDS value of 10,000 ppm. Infiltration of sodium-chloride waters into the transition zone is a concern: Groundwater withdrawal within the transition zone has resulted in local drops of head and increased chloride concentrations in some water wells (Macfarlane, 2010). The transition zone of Figure 6 is consistent with a regional aquifer study by Jorgensen et al. (1993, p. 44-46), which found that the area in eastern Kansas is a zone of hydrologic convergence and mixing for waters from the west and the east. Chemical analysis of water well samples from Cambrian-Ordovician and Mississippian aquifers substantiated the mixing of waters in southeastern Kansas and northeastern Oklahoma, and also provided evidence for a third end member, sourced from the Anadarko Basin (Musgrove and Banner, 1993).

In summary, a high-salinity brine plume pervades Paleozoic strata, with a main body located in southcentral Kansas and north-central Oklahoma, and a lobe extending into south-central Oklahoma (Figure 7). The main body of the brine plume lies mostly west of the line marking the base of the Wellington Formation and the eastern extent of Permian salt. The plume was derived from the dissolution of Permian salts and subsequent downward, density-driven migration. Jorgensen et al. (1993) and Banner et al. (1989) previously recognized the approximate alignment of halite and the eastern edge of dense brine, and acknowledged the conceptual problem of downward migration through Pennsylvanian strata, which were regarded as a confining system. However, a hydrologic simulation along a cross section very similar to that of Figure 3 resulted in brine-saturated formations below the evaporite sequence, indicating that buoyancy-driven downward migration is possible (Thornton and Wilson, 2007). We maintain that downward movement of dense brine along faults and fractures is a reasonable explanation for the pervasive plume. Otherwise, it is difficult to account for a 
five-to-tenfold increase in salinity above that of seawater without a halite-dissolution source. The lobe in south-central Oklahoma extends east of the base of the Wellington, and its presence there requires either eastward migration of the plume or the presence of another brine source. Eastward migration could have occurred through faults or structures lying east of the Nemaha uplift. One such structure is the Cushing fault zone and uplift (Figures 7, 8, respectively). The amount of offset depicted on the Cushing uplift is represented in the Cushing oil field, an elongate structure extending $24 \mathrm{~km}$ (15 mi) northsouth that is bisected by the section along latitude $36^{\circ} \mathrm{N}$ shown in Figure 8. Short en echelon faults trending northwest-southeast persist north and south of Cushing field and also exist along other northsouth trends located both west and east of the Cushing trend (Figure 8). These fault systems appear to be extensional without any mapped strike-slip displacement along trend (Miser, 1954). Alternatively, the southern lobe of the plume could be sourced by a third groundwater type identified by Musgrove and Banner (1993), with its spatial distribution influenced by the Nemaha uplift and the Cushing fault zone.

\section{COMPUTATION OF HYDRAULIC HEAD AND POTENTIOMETRIC SURFACES}

Under certain assumptions reviewed below, hydraulic head $H$ can be computed as the sum of two components (Hubbert, 1956, p. 50)

$$
H=Z+P / \rho g
$$

where $Z$ is the mean elevation of the perforated interval with respect to sea level, $P$ is the formation pressure, $\rho$ is the density of water, and $g$ is the acceleration of gravity. The term $\rho g$ is often referred to as the pressure gradient. In oilfield units, $Z$ is in feet, $P$ is in psi, $\rho g$ is in psi/ft, and consequently $H$ is in feet. Pressure is measured with a DST in an oil or gas reservoir that is presumed to be aquifer supported or at least in hydraulic connection with a pervasive water-bearing system. This assumption allows the conversion of pressure to hydraulic head, as illustrated in Figure 10, in which all pressure values within $9.7 \mathrm{~km}$ (6 mi) of an arbitrary west-east line are shown, along with derived values of $H$ and the pressure:depth ratio $P / D$.

\section{An Illustrative Cross Section}

Most values of pressure $P$ are less than actual in situ formation pressure, causing most values of $H$ and $P / D$ to be erroneously low (Figure 10). Figure 10 is for illustrative purposes only; the method actually used to select points for a mappable potentiometric surface is described below. A light blue curve was drawn by hand along the upper surface of pressure data to represent the in situ pore pressure (pressure profile in Figure 10). Similar curves were drawn to represent the hydraulic head $H$ and the pressure:depth ratio $P / D$. Inspection of Figure 10 illustrates several points regarding the pressure data and its conversion to head as follows:

1. Because most drill-stem pressure measurements $P$ are less than actual in situ pressure, only a small fraction can be used to define a potentiometric surface.

2. Formation elevation $Z$ is concave upward as the west-east section traverses the bowl-like subsurface topography of the northern flank of the Anadarko Basin (see Figure 2).

3. The pressure surface $P$ is convex upward in response to the spatial variation in the formation surface $Z$.

4. When the convex curve $P$ and the concave curve $Z$ are combined in accordance with equation 1 , the result is a nearly flat hydraulic head $H$.

5. The spatial character of $P / D$ is not obvious from inspection of the other surfaces, although the separation $S-H$ is roughly proportional to $P / D$. Underpressure is greatest at the western end of the section, as shown by the maximum of $S-H$ and the minimum of $P / D$.

\section{The Variable Density Problem}

Equation 1 is applicable if (1) the flow velocity is negligible, so kinetic energy is unimportant compared to potential energy; (2) water is the continuous phase, as it appears to be in most of the area considered in 
Figure 10. Drill-stem test (DST) data from Missourian rocks along a west-east transect. Surface locations of wells define the land elevation $S$. Each DST is represented by a symbol at elevation $Z$ and pressure $P$, along with derived values of head $H$ and pressure:depth ratio $P / D$. Hand-drawn light blue lines $H, Z, P$, and $P / D$ indicate the regional trends of actual in situ values. See discussion of equations 2 and 3 for relation between $P / D$ and surfaces $S, H$, and $Z$.
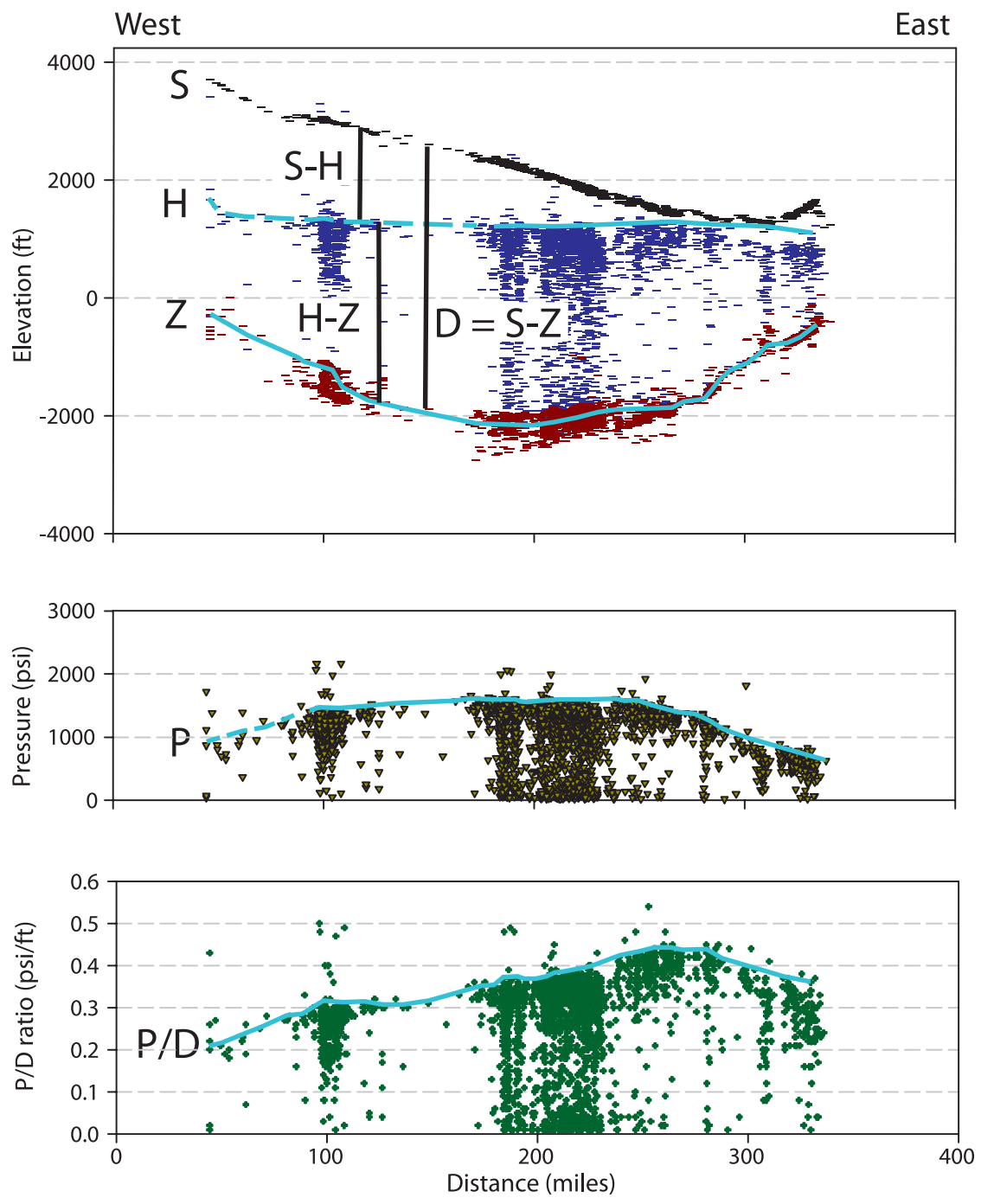

this paper, rather than gas or oil; and (3) fluid density is constant. The third assumption does not hold across the Midcontinent, as demonstrated in the preceding discussion of the high-salinity plume, thereby complicating the interpretation of flow from a potentiometric surface.

In most hydrologic applications, a potentiometric surface composed of all applicable values of $H$ is derived so that the direction of flow can be determined by examining the spatial gradient of $H$. However, where the density $\rho$ varies spatially, the flow field cannot be determined from a potentiometric surface (Hubbert, 1956, p. 49-51; Bachu, 1995). As a consequence, the contours of $H$ presented in this paper cannot be used to infer a flow direction in regions in which density varies spatially, and in particular, around the edges of brine plumes. Even with this limitation, the computation of $H$ in accordance with equation 1 is useful and necessary to understand the variation in subsurface pressure across the broad region of the Midcontinent, because elevation changes are taken into account. Although the flow field cannot be derived in areas where salinity varies, the flow direction can be examined in areas where salinity varies little, and more importantly for the purpose of this paper, potentiometric surfaces from different hydrogeologic units can be compared where the patterns of salinity variations and subsurface topography are comparable. Finally, although salinity variations can warp the potentiometric surfaces, the 
maps of pressure and pressure:depth ratio are unaffected because the edited pressure data are used directly in those maps.

\section{Creating a Potentiometric Surface}

We next consider the process for selecting values for each of the three quantities in equation 1 . Further details are available in Gianoutsos and Nelson (2013).

The elevation $Z$ is taken as the midpoint of the DST interval. Tests with large vertical separations between bottom and top of the test interval were eliminated using the criterion that the difference between the bottom and top depths must be less than 0.1 times the bottom depth. Erroneous elevation values that were greatly offset from the rest of the formation were also removed. Finally, data were eliminated if the surface elevation recorded for a well in the database differed from land-surface elevation.

Based on geologic formation, DSTs taken from IHS Energy (2012) were assigned to the seven hydrogeologic units shown in Figure 5. The majority of tests were run between 1950 and 1990, although some tests were acquired as early as 1942 and as recently as 2011. Only a fraction of DSTs measure the actual formation pressure $P$, and these are selected after conversion of $P$ to $H$. The larger of the initial and final pressures recorded by a DST was converted to $H$ using equation 1 . Selection of representative values to define a potentiometric surface is difficult, because most of the pressure data are not preproduction reservoir (aquifer) pressures, but are either less due to imperfect tests or production drawdown, or are greater due to local overpressured compartments. Local zones of overpressure at scales up to $48 \mathrm{~km}$ (30 $\mathrm{mi}$ ) have been ignored to produce a smoothly varying surface. In earlier work, a method using software developed for processing geophysical potential-field data and incorporating filtering operations was used to select representative head values (Nelson and Gianoutsos, 2014b). In the present work, data were processed in orthogonal swaths and examined in a three-dimensional (3-D) viewer.

To select a subset of data points representative of a potentiometric surface, the hydraulic head values for a hydrogeologic unit were divided into swaths with a width of $0.5^{\circ}$ latitude or approximately $56 \mathrm{~km}$ (35 mi), as illustrated by the example of Figure 11. Data from each swath were examined in a plot of $H$ versus distance to select points that best define the surface of the hydraulic head values in that swath (blue dots in Figure 11A, B). In this example, the top of densely packed points cannot be distinguished west of $-102.0^{\circ}$, so the surface is not defined west of that longitude on this particular swath.

This process was repeated using swaths along the orthogonal direction, based on $0.5^{\circ}$ of longitude. By combining and analyzing the data from the two perpendicular directions, it becomes easier to determine if trends in the potentiometric surface are represented in both directions, which helps to validate the data. In areas where data are erratic, overly sparse, or where substantial areas of overpressure exist, no points were selected.

All data points selected from the latitudinal and longitudinal swaths were combined into one data set that will contain duplicates. For example, in the Desmoinesian potentiometric subset, 957 duplicates were found as a result of viewing the data in perpendicular directions, in addition to 2197 unique values. The combined surface was then analyzed for any values that appeared out of place. For example, a trend might appear in the latitude swath that was not supported in the longitude view. In these instances, the questionable points were removed from the edited data set.

For each hydrogeologic unit, a surface representing the interpreted potentiometric surface was created from the subset of selected hydraulic head values. However, subset values were not selected in the area of overpressure in the deep Anadarko Basin located in central western Oklahoma and the eastern Texas panhandle. To contour the potentiometric surfaces, $H$ values were color coded by $61-\mathrm{m}$ (200-ft) intervals, and contours were drawn by hand at the transition between color groups. This method proved more satisfactory than machine contouring.

The interpreted potentiometric surface can be overlain on the complete data set of hydraulic head values for each hydrogeologic unit. By viewing the data in this way, it was possible to fly through the data in a 3-D viewer and assess how well the potentiometric surface reflects the top of the data set. Points located a 
Figure 11. (A) Plan view of wells with calculated head values from drill-stem tests in Mississippian rocks in a swath $0.5^{\circ}$ wide between latitudes $37.0^{\circ} \mathrm{N}$ and $37.5^{\circ} \mathrm{N}$. (B) Head values from the swath as a function of elevation relative to sea level. Head values are more densely packed below an elevation of $305 \mathrm{~m}$ (1000 ft); values at the upper fringe of the densely packed interval were selected for mapping and are highlighted in blue in both parts $(A)$ and $(B)$. Diffuse values above the blue points are attributed to isolated compartments that are somewhat overpressured.

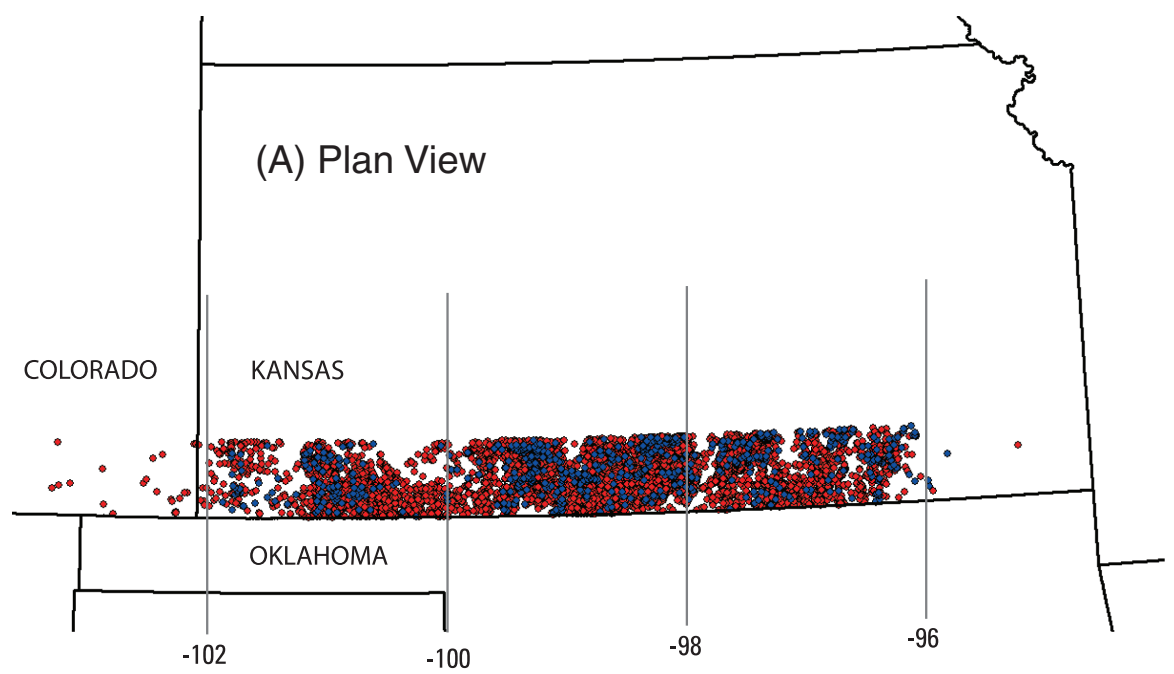

(B) Section View

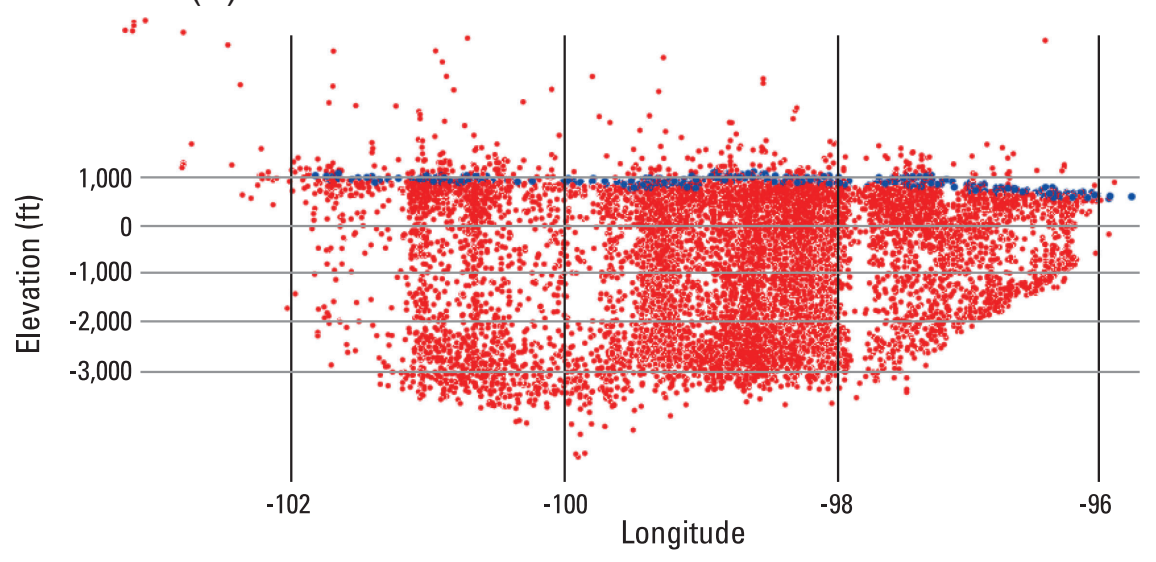

significant distance above the surface are either outliers or overpressured and points below the surface are generally considered to be DSTs that did not measure the preproduction formation pressure. State lines and faults, structural features, and areas of interest can be projected onto the surface to provide a frame of reference for the viewer (Figure 12).

\section{Sources of Error}

Sources of error in determining valid pressure or head values are as follows.

\section{Elevation $Z$ of Permeable Zone}

The permeable zone providing the maximum pressure could be at any elevation between the top and bottom of the perforated zone. The height of the vertical DST interval varies from test to test; a few long test intervals cause the height distribution to be right skewed. For example, the median, average, and standard deviation of 2197 test intervals in Desmoinesian rocks are 10, 13, and $15 \mathrm{~m}$ (32, 43, and $49 \mathrm{ft}$ ), respectively. Large errors in elevation cause a given $H$ value to fall outside the band of selected values. Using one-half the standard deviation of the interval as a measure of elevation error, we estimate an uncertainty in vertical location of approximately $8 \mathrm{~m}(25 \mathrm{ft})$.

\section{Thickness of Selected $H$ Values}

Viewed in cross section, the points selected for each swath occupy a diffuse layer that can be as thick as $30 \mathrm{~m}(98 \mathrm{ft})$, but is typically approximately $15 \mathrm{~m}$ $(50 \mathrm{ft})$. Points that appear adjacent to each other on the cross section (Figure 11B) may be many miles apart in plan view (Figure 11A). By examining the vertical range of a selected subset (blue points in Figure 11B), we estimate that errors in elevation due 


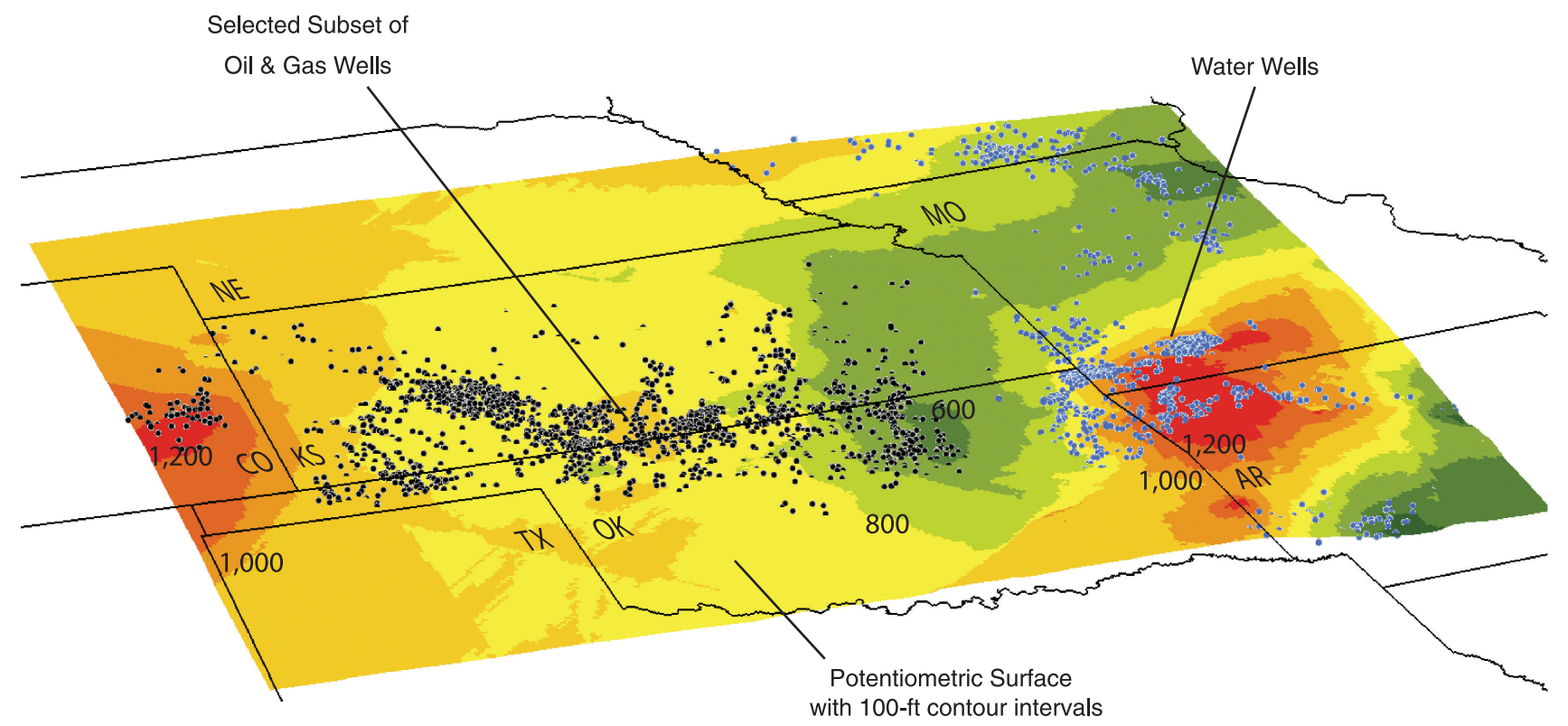

Figure 12. Oblique view of the Mississippian potentiometric surface and the locations of oil and gas wells (dark blue dots) and water wells (light blue dots) used to define it. Contours beyond extent of data are poorly constrained and not used in subsequent presentations.

to the selection method to be approximately $\pm 7.5 \mathrm{~m}$ $( \pm 25 \mathrm{ft})$. Errors in elevation and errors due to the finite swath layer are both nonsystematic and do not bias the resulting potentiometric surface.

\section{Pressures in Oil and Gas Fields}

Reservoir pressure will be greater than pressure in an equivalent water column due to the buoyancy of gas or oil. Finite column heights produce a value of $H$ greater than that of the underlying aquifer. For example, for a specific gas density of 0.5 , a pressure measurement at the top of a $61-\mathrm{m}(200-\mathrm{ft})$ gas column would result in a head value that would be $30 \mathrm{~m}$ $(100 \mathrm{ft})$ too high. The effect of variable hydrocarbon columns results in an upward bias that is randomly distributed. The thickness of Mississippian chert reservoirs ranges from 3 to $21 \mathrm{~m}$ (10 to $70 \mathrm{ft}$ ), so the upward bias could range from 1.5 to $10.5 \mathrm{~m}$ (5 to $35 \mathrm{ft})$.

\section{Pressure Drop with Time}

Because the highest head values are selected, preproduction values are preferentially selected over the reduced heads typically associated with pressure depletion in compartmentalized reservoirs. Consequently, the error associated with pressure drop due to production is assumed to be negligible.

\section{Density}

Although density varies with pressure, temperature, and salinity, the effects of pressure and temperature tend to cancel, and therefore, salinity variations are the most important factor in density variations, especially in the Midcontinent where high-salinity brines are present in deep strata. In applying equation 1 , a value of $10.5 \mathrm{kPa} / \mathrm{m}(0.465 \mathrm{psi} / \mathrm{ft})$ was used for $\rho g$ for all hydrogeologic groups, except the Cretaceous, for which a freshwater value of $9.8 \mathrm{kPa} / \mathrm{m}(0.433 \mathrm{psi} / \mathrm{ft})$ was used. A value of $10.5 \mathrm{kPa} / \mathrm{m}(0.465 \mathrm{psi} / \mathrm{ft})$ is equivalent to a brine concentration of 101,737 ppm (Table 1).

From equation 1 , it can be seen that $H$ computed for water with $\rho g$ less than $10.5 \mathrm{kPa} / \mathrm{m}(0.465 \mathrm{psi} / \mathrm{ft})$ will be greater than that computed for a value of $10.5 \mathrm{kPa} / \mathrm{m}(0.465 \mathrm{psi} / \mathrm{ft})$. Conversely, $\rho g$ greater than 0.465 will produce a lower $H$ value than that computed for $10.5 \mathrm{kPa} / \mathrm{m}(0.465 \mathrm{psi} / \mathrm{ft})$. The amount of offset is independent of the DST elevation but depends on the pressure (Table 1). For example, at a pressure of $10.3 \mathrm{MPa}$ (1500 psi) and an actual $\rho g$ of $10.1 \mathrm{kPa} / \mathrm{m}(0.445 \mathrm{psi} / \mathrm{ft}$ ) (seawater salinity), the actual $H$ is $44 \mathrm{~m}(145 \mathrm{ft})$ higher than $H$ computed for a $\rho g$ value of $10.5 \mathrm{kPa} / \mathrm{m}$ (0.465 psi/ft). 
As shown in Table 1, if the pressure is $7 \mathrm{MPa}$ (1000 psi) or greater, then the offset or error in $H$ due to density variations can be greater than the previously cited errors due to elevation $Z$ or pressure $P$. Offsets due to density variations are greatest in areas in which pressure is high (Figure 13) and salinity causes $\rho g$ to deviate substantially from $10.5 \mathrm{kPa} / \mathrm{m}$ (0.465 psi/ft) (Figures 6, 7). Pressure increases from north to south (Figure 13), reflecting the arcuate topography imposed by the Anadarko Basin (Figure 2), whereas salinity is greatest within the kidney-shaped outlines of the high-salinity plumes shown in Figure 7. Thus, an unwanted increase in the height ("pullup") of the surfaces will be greatest in central Oklahoma along the Nemaha uplift, and along the northern tier of Oklahoma counties, in which both salinities and pressures are high. Pullup will decrease northward into southern Kansas in which pressures are generally less than $14 \mathrm{MPa}$ (2000 psi). On the other hand, in eastern Colorado, western Kansas, and the Oklahoma panhandle, where salinities are less than $100,000 \mathrm{ppm}$, the potentiometric surfaces computed with $\rho g$ equal to $10.5 \mathrm{kPa} / \mathrm{m}(0.465 \mathrm{psi} / \mathrm{ft})$ will be too low ("pushdown"). Both pullup and pushdown will be greatest in the older, deeper hydrogeologic units where pressure is highest (compare Figure 13A with 13F). Fortunately for our analysis, in eastern Kansas and Oklahoma where burial depths are minimal, pressures are less than $7 \mathrm{MPa}$ (1000 psi) (Figure 13). Consequently, distortions in the potentiometric surfaces are minimal (less than $30 \mathrm{~m}$ [100 ft]) in those areas in which we will be examining the connection between hydraulic head and outcrop.

\section{POTENTIOMETRIC SURFACES}

The potentiometric surfaces generated as part of this study (Figures 14, 15) are based on data from DSTs in oil and gas wells combined with data from water wells (US Geological Survey, 2012). In the western and central parts of the maps, pressure was converted to hydraulic head $H$ (equation 1), subject to the uncertainties discussed in the preceding section "Computation of Hydraulic Head and Potentiometric Surfaces." The number of DSTs used to create the 7 potentiometric surfaces ranges from approximately 750 for the Permian surface to 5500 for the
Missourian surface. In the eastern part of the study area, hydraulic head was equated to water levels measured in water wells. Water wells are generally located within outcrop belts of the same geologic age, where strata of a given hydrogeologic group are very close to the land surface. Contours of hydraulic head span the transition from water levels in water wells to hydraulic head computed from DSTs. The potentiometric surfaces for the six Paleozoic hydrogeologic units (Figure 14) are discussed first, followed by a discussion of the Lower Cretaceous potentiometric surface (Figure 15).

\section{Hydraulic Head in Paleozoic Strata}

In central and eastern Kansas and Oklahoma, the potentiometric surfaces (Figure 14) display low gradients with heads approaching land-surface elevations in the vicinity of their respective outcrops. For example, Permian hydraulic heads of $366 \mathrm{~m}$ $(1200 \mathrm{ft})$ straddle the Permian outcrop and the Nemaha uplift immediately west of the 305-m (1000-ft) land-surface contour (Figure 14A). Similar relationships are seen in Virgilian, Missourian, and Desmoinesian maps (Figure 14BD). These four maps illustrate a central tenet of this paper: As a formation shallows, the formation pressure is referenced to atmospheric pressure and the potentiometric surface approaches land surface, thereby establishing an important control on the entire potentiometric surface. The locus of equilibrium between aquifer and atmosphere is distributed along the extent of outcrop; no single point of equilibrium can be located.

A gap of $32-80 \mathrm{~km}(20-50 \mathrm{mi})$ separates the easternmost oil and gas wells from the westernmost water wells, although the two data types appear intermingled in a few locations. The gap between water wells and wells with DSTs lies in southeastern Kansas in the Cambrian-Ordovician-Silurian and Mississippian hydrogeologic units (Figure 14E, F) and lies progressively westward in younger hydrogeologic units, so that the gap in the Permian unit (Figure 14A) lies $160 \mathrm{~km}(100 \mathrm{mi})$ west of the Cambrian-Ordovician-Silurian hydrogeologic unit. This westward progression with younger hydrogeologic units is consistent with the westward 

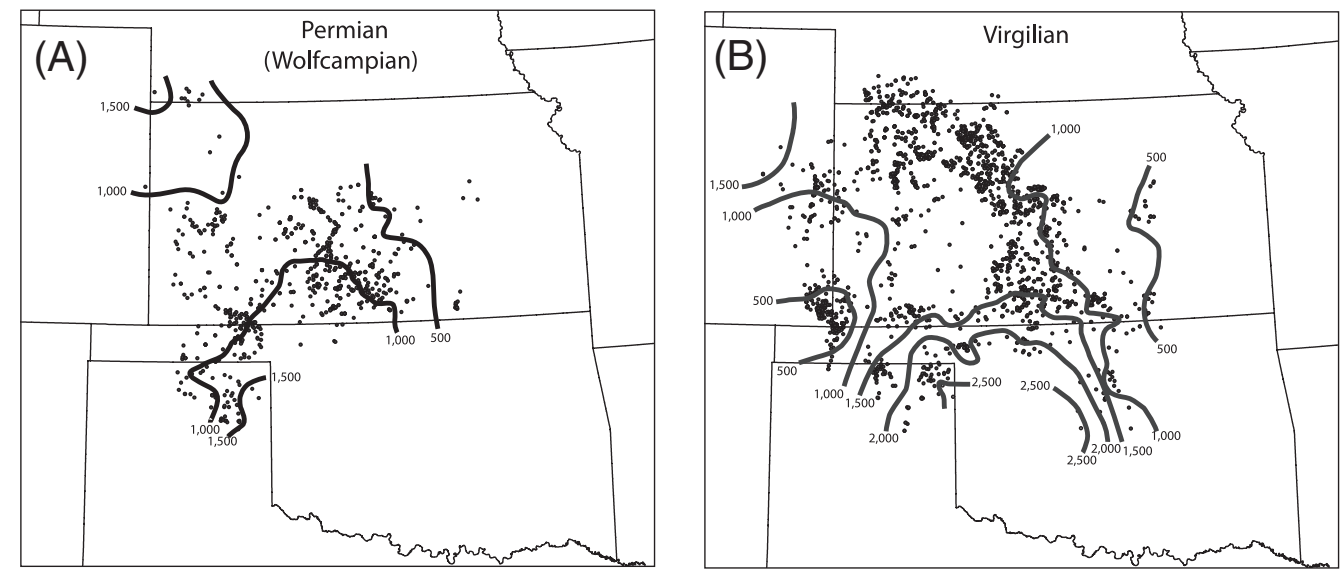

Figure 13. Pressure in pounds per square inch (psi) in six hydrogeologic units. Pressure data correspond to the subset of drill-stem tests used to contour hydraulic head in Figure 14 and also conceptually correspond to the light blue line labeled " $P$ " in Figure 10. Small dots show well locations.
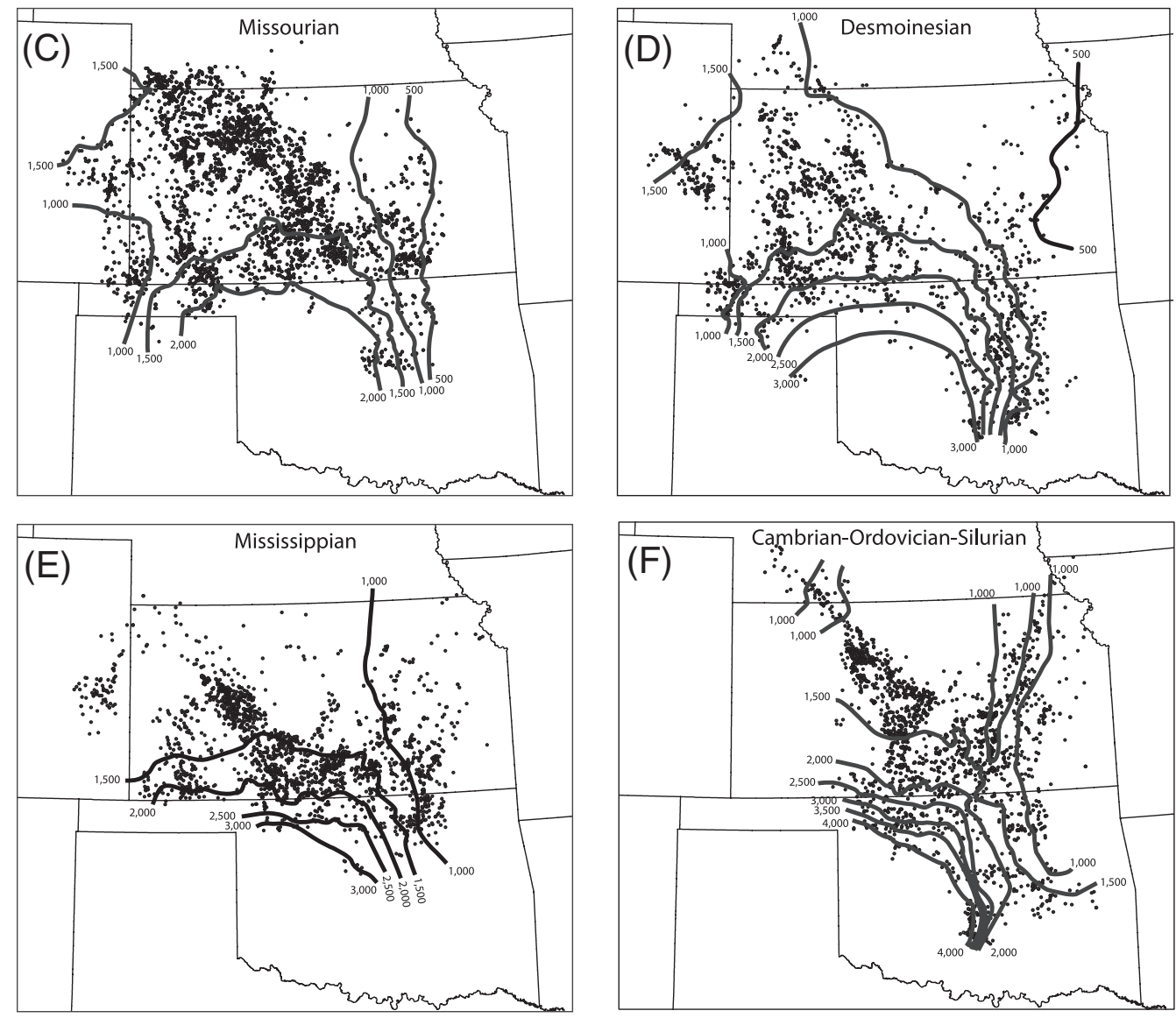

progression of younger outcrops shown in Figures 4 and 14.

Outcrop cannot control the potentiometric regimes of the Mississippian and CambrianOrdovician-Silurian units (Figure 14E, F), because outcrops and water wells are located on the Ozark Plateaus in southwestern Missouri and northwestern Arkansas at elevations greater than the potentiometric lows of less than $183 \mathrm{~m}(600 \mathrm{ft})$. For these two hydrogeologic units, the equilibration areas appear to be in eastern Oklahoma along the Arkansas River Valley, based on the proximity of the $183-\mathrm{m}(600-\mathrm{ft}) H$ contour and the 152-m (500-ft) land-surface contour. In this area, these two hydrogeologic units are essentially equivalent to the Ozark Plateaus aquifer system of Jorgensen et al. (1993). Minima of less than 

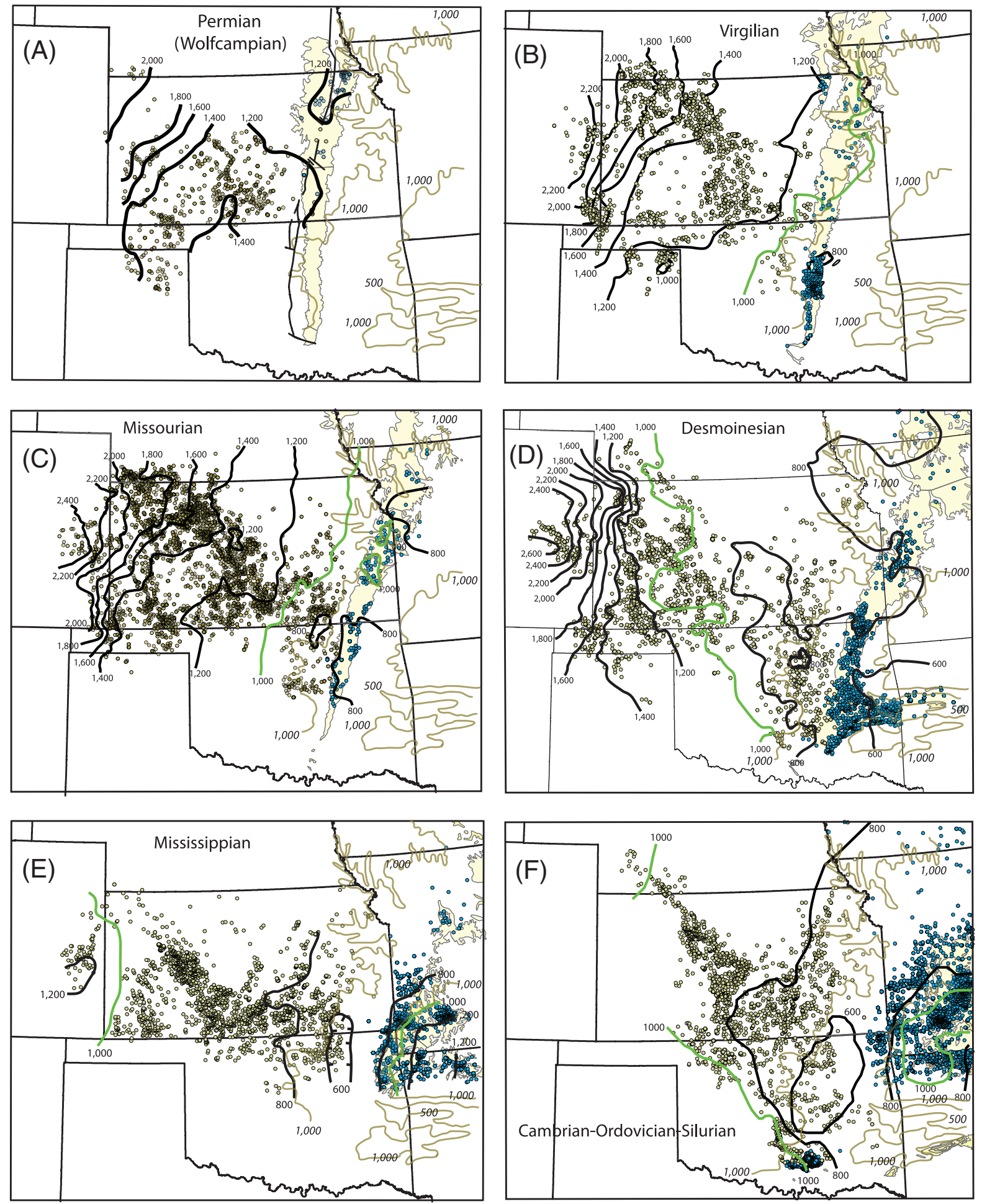

Figure 14. Potentiometric surfaces (in feet) in six hydrogeologic units, computed from drill-stem tests (brown dots) and measured in water wells (blue dots). Water wells are located within or near the areas of outcrop from Schruben et al. (1997), shaded light yellow. Black contours at 61-m (200-ft) intervals give hydraulic head, with green contours at $305 \mathrm{~m}$ (1000 ft) allowing comparison of head among the hydrogeologic groups. Light brown contours at 152 and $305 \mathrm{~m} \mathrm{(500} \mathrm{and} 1000 \mathrm{ft}$ ) give land-surface elevation in eastern part of the study area. A 305-m (1000-ft) contour outlines the Ozark Plateaus in southwestern Missouri and northwestern Arkansas. A 152-m $(500-\mathrm{ft})$ contour in east-central Oklahoma extending into west-central Arkansas outlines the Arkansas River Valley. Nemaha uplift shown in part $(A)$. 


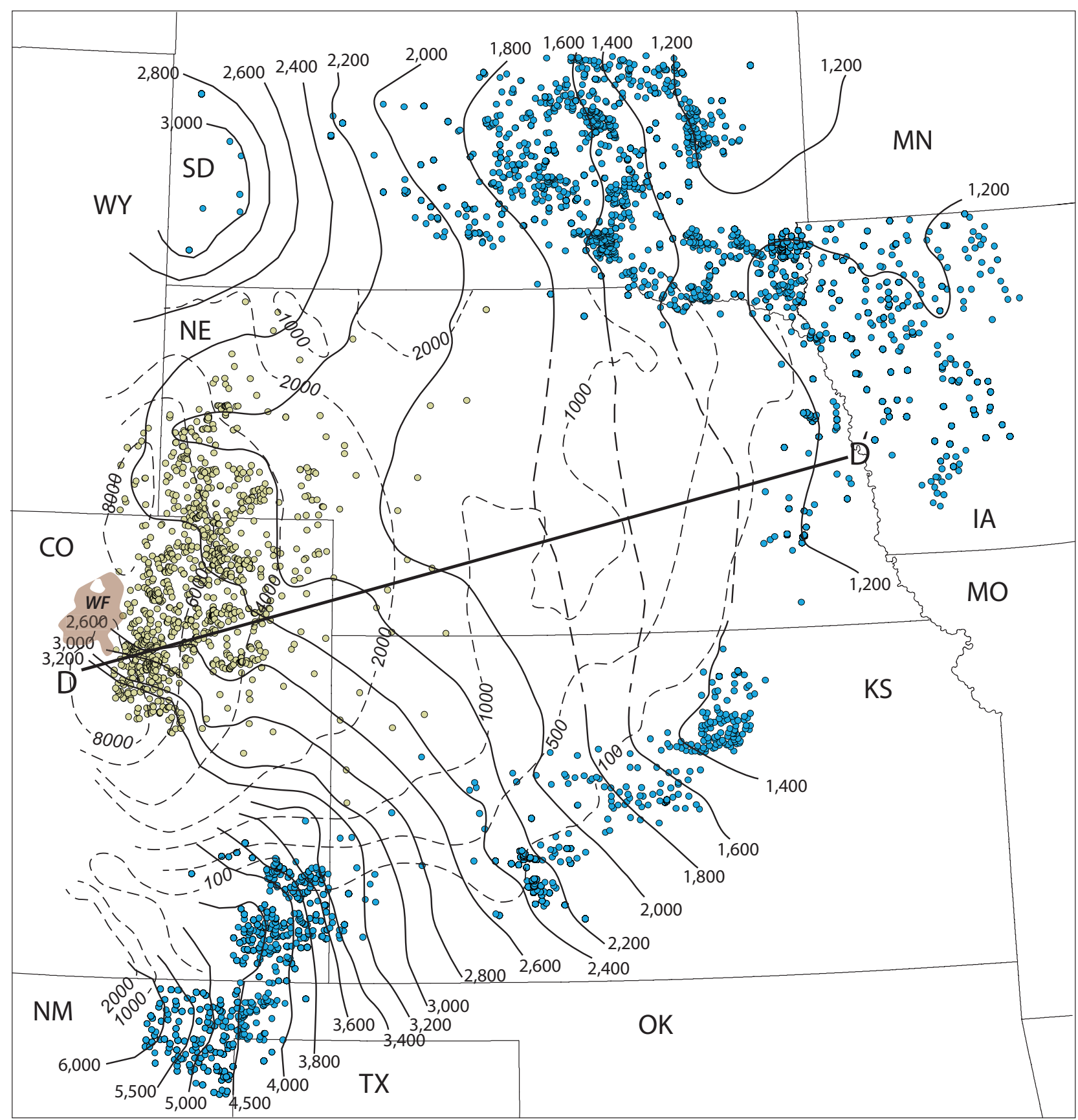

Figure 15. Potentiometric surface in feet (heavy solid lines) for the Lower Cretaceous Dakota Group, computed from drill-stem tests

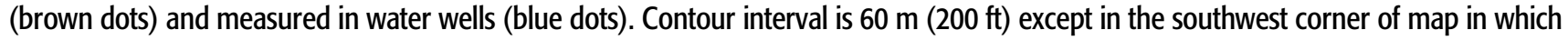
the interval is variable; dashed parts of solid contours indicate uncertainty due to lack of data. Light dashed contours show thickness of Cretaceous shales in feet overlying the Dakota Group, taken from Jorgensen et al. (1993, their figure 43), courtesy of US Geological Survey. Line DD' shows location of cross section in Figure $16 . \mathrm{WF}=$ Wattenberg gas field.

$183 \mathrm{~m}(600 \mathrm{ft})$ in eastern Kansas and Oklahoma lie between head levels greater than $305 \mathrm{~m}(1000 \mathrm{ft})$ in southwestern Missouri and levels greater than $305 \mathrm{~m}$ $(1000 \mathrm{ft})$ in western Kansas (Figure 14E, F). Recognizing these minima, Jorgensen et al. (1993, their figure 6) proposed a transition zone in western Missouri, southeastern Kansas, and northeastern Oklahoma where eastward flow from the Western Interior Plains aquifer system meets westward flow from the Ozark Plateaus aquifer system. In 
southeastern Kansas, a 48 to $96-\mathrm{km}$ (30 to 60-mi) wide transition zone separating the sodium-chloride groundwaters of the Western Interior Plains aquifer system from the low-dissolved-solids groundwater of the Ozark Plateaus was investigated by Macfarlane (2010), concerned that overdevelopment of groundwater supplies in the transition zone (represented by the westernmost water wells in Figure 14E, F) could lead to eastward encroachment of saline groundwaters and deterioration of water supplies.

The most significant features of the six potentiometric maps (Figure 14) are the low horizontal hydraulic gradients in central and eastern Kansas and Oklahoma, in which head values are less than $427 \mathrm{~m}$ (1400 ft). In contrast, in western Kansas and eastern Colorado, the potentiometric surfaces of the four younger hydrogeologic units (Figure 14A-D) display high horizontal gradients with head values exceeding $610 \mathrm{~m}(2000 \mathrm{ft})$ near the ColoradoKansas border. The high gradients, which indicate low permeability, lie in the general area of the Las Animas arch, and seem to be associated with the thinning of carbonate units and a corresponding increase in silty and shaly units on the Las Animas arch that separate areas of carbonate deposition in western Kansas from similar areas in eastern Colorado (Mallory, 1972; Rascoe and Baars, 1972; Rascoe, 1978).

In contrast, the Mississippian surface maintains a low gradient into eastern Colorado with hydraulic head values approximately $305 \mathrm{~m}$ (1000 ft) lower than the Permian and Pennsylvanian surfaces (compare Figure 14E with 14A-D). The contrast between unusually low pressures (and heads) in Mississippian reservoirs and higher pressures (and heads) in Pennsylvanian reservoirs on the Las Animas arch was noted by Clair and Volk (1968) and Merewether (1987). In south-central Kansas, the presence of high-porosity Mississippian chert reservoirs (called "chat") resulted from diagenesis due to subaerial exposure and structural features. Porosity in chat reservoirs ranges from $20 \%$ to $50 \%$ and permeability ranges from 5 to $500 \mathrm{md}$ (Watney et al., 2001). With sufficient lateral interconnection, such facies could readily account for the low gradient in Mississippian strata in south-central
Kansas. Similar observations apply to eastern Colorado (Jorgensen et al., 1993, p. B28). Erosion and deep weathering of the Mississippian surface and deposition of reworked chert (Merriam, 1963, p. 135) likely created sufficient permeability on the regional scale to create a high-permeability network consistent with the low-gradient surface of Figure 14E.

Although previous investigators have determined that the Permian and Pennsylvanian sequences are low-permeability aquitards (Belitz and Bredehoeft, 1988; Jorgensen et al., 1993), the potentiometric maps (Figure 14A-D) display sufficient continuity to be regarded as aquifers, albeit with hydraulic coupling to overlying and underlying hydrogeologic units. In particular, potentiometric contours of the Permian (Wolfcampian), Virgilian, and Missourian hydrogeologic units display sufficient similarity to suggest vertical communication among these units. The effect of the Nemaha uplift is uncertain. The uplift coincides with Wolfcampian outcrop in Kansas (Figure 14A) and could play a role with Permian equilibration. However, midPennsylvanian through Permian strata are continuous, although faulted, across the uplift (Figure 3), so the effect of the uplift on hydrologic continuity may be minimal.

The hydrologic continuity expressed in Figure 14 requires permeability sufficient to develop and maintain it; the higher levels of permeability may be due in part to faults and fractures. Rather than a broad continuous shelf with few structural features, Watney et al. (2008) find that faults reactivated during deposition of Mississippian and Pennsylvanian sequences led to structural blocks with subtle variations in relief. Their analysis of thickness changes identified blocks $10 \mathrm{~km}$ (6 mi) in size separated by lineaments, and inspection of well data, seismic data, and rock properties for six Kansas oil fields in Mississippian, Desmoinesian, and Missourian intervals also led to the identification of structures on a scale ranging from 1 to $10 \mathrm{~km}(0.6$ to $6 \mathrm{mi})$ in size. They surmise that "structural movement of these blocks concurrent with deposition and early diagenesis significantly influenced rock properties and reservoir development, and fracture sets (joints) locally affect past and present 
reservoir connectivity and permeability" (Watney et al., 2008, p. 4). These observations indicate structural enhancements to both horizontal and vertical regional permeabilities.

\section{Hydraulic Head in Lower Cretaceous (Dakota) Strata}

The DSTs in oil and gas wells are concentrated in the Denver Basin of northeastern Colorado with a few scattered onto the basin flanks in northwestern Kansas, western Nebraska, and southeastern Wyoming (Figure 15). Water salinities in Lower Cretaceous formations are generally much lower than in Paleozoic formations, so a $\rho g$ value of $9.8 \mathrm{kPa} / \mathrm{m}(0.433 \mathrm{psi} / \mathrm{ft})$ was used to convert pressure from DSTs to hydraulic head (equation 1). Water wells form a broad arc extending from northwestern New Mexico across central Kansas into eastern Nebraska and western Iowa, before arcing westward into central South Dakota. The combined values of $H$ from DSTs and water wells resulted in a potentiometric surface (Figure 15) that generally reproduced the features of an earlier map by Helgesen et al. (1993, pl. 5). A cross section from Denver, Colorado, to Blair, Nebraska (Figure 16), illustrates the continuity and elevation change of Lower Cretaceous sandstones across the extent of the map and also displays the hydraulic head along the section. The thickness of Cretaceous shales overlying the Dakota Group (light dashed contours in Figure 15) exceeds $2438 \mathrm{~m}(8000 \mathrm{ft})$ in the Denver Basin. These contours represent the Great Plains confining system of Jorgensen et al. (1993); the stratigraphic relationship is shown in Figure 5.

The geographic distribution of wells in Lower Cretaceous rocks and the resulting potentiometric surface differ significantly from those in Paleozoic rocks (compare Figure 15 with Figure 14). Unlike the Permian and Paleozoic maps (Figure 14), the Cretaceous potentiometric contours show no change in gradient in the vicinity of the Las Animas arch in western Kansas and eastern Colorado. The northeasterly flow direction indicated by the Cretaceous potentiometric surface in western Kansas is orthogonal to the southeasterly gradient in the Permian (Wolfcampian) unit (Figure 14A). These and other features indicate little coupling between the Lower Cretaceous (Dakota) and the Permian (Wolfcampian) hydrologic systems, with the intervening Permian evaporites (Figures 8,9 ) isolating the two systems. Lack of coupling was also indicated by modeling Cretaceous hydraulic heads with and without the presence of older units (Belitz and Bredehoeft, 1988, p. 1351).

The northern belt of water wells in South Dakota represents part of a hydrological system that is recharged in western South Dakota and, lacking much outcrop exposure in the east, behaved as an

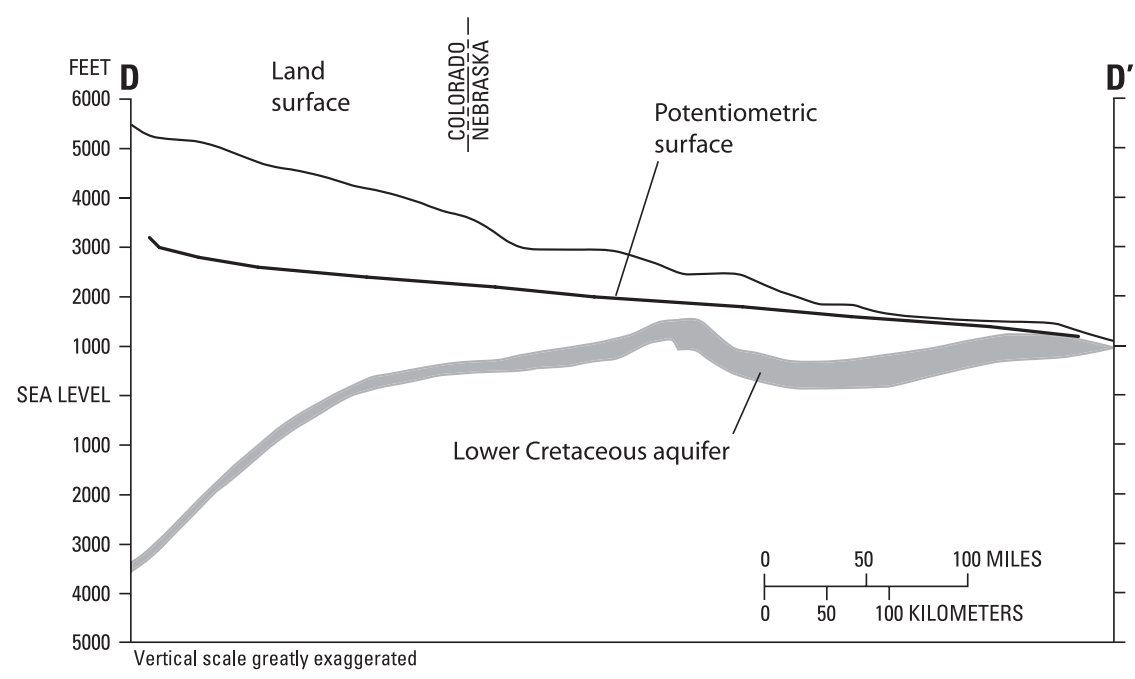

Figure 16. Cross section $\mathrm{DD}^{\prime}$ from Denver, Colorado, to Blair, Nebraska, showing potentiometric surface and elevation of Lower Cretaceous aquifers across eastern Colorado and Nebraska. Section modified from Helgesen et al. (1993, their figure 13), courtesy of US Geological Survey. Location of cross section shown in Figure 15. 
artesian system prior to extensive development (Bredehoeft et al., 1983). Along the southern belt of water wells in southeastern Colorado and western Kansas, Macfarlane (1995) documented recharge in the west, a general state of underpressure wherever the Dakota is isolated from surface alluvium or other aquifers, and discharge in the east where rivers cut outcrop. In brief, the southern and northern belts of Lower Cretaceous (Dakota) water wells depicted in Figure 15 have been considered as separate and distinct hydrological systems. Although the potentiometric map (Figure 15) suggests the possibility of recharge from the south and north into the deeper central portion of the Denver Basin of Colorado, the amount of such recharge cannot be estimated without detailed modeling. One such effort by Belitz and Bredehoeft (1988, p. 1348) determined that the Denver Basin is hydrologically in contact with outcrop north of Boulder, Colorado, but is isolated from outcrop between Boulder and Colorado Springs, in which upturned and faulted strata limit hydrologic continuity. Belitz and Bredehoeft (1988) also pointed out that low permeability in the deep basin serves to limit recharge from outcrop exposures. Altogether, the evidence indicates that flow in the near-surface, high-permeability Dakota aquifer is governed by western recharge and eastern discharge along the southern (Kansas) band of outcrop and is probably a limited source of recharge to the deep Denver Basin.

\section{MAPS OF PRESSURE:DEPTH RATIO}

After the hydraulic head values forming the potentiometric surface were selected, the pressure:depth $(P / D)$ ratios for that data subset were mapped for each of the seven hydrologic units (Figures 17, 18). Consequently, the maps of pressure:depth ratio are based on the same subset of user-selected DST data as the potentiometric surfaces, rather than from all available pressure data. Keep in mind that selection of points for potentiometric surfaces excluded local areas of overpressure, and as a consequence, local overpressured areas are not represented in Figures 17 and 18. The overpressured deep part of the Anadarko Basin, as depicted by the $11.3 \mathrm{kPa} / \mathrm{m}$
(0.5 psi/ft) line of Figure 7 for Desmoinesian rocks, is excluded from the maps of Figure 17.

Maps of pressure:depth ratio in Paleozoic rocks (Figure 17) show a progressive decrease from normally pressured values exceeding $10.2 \mathrm{kPa} / \mathrm{m}$ $(0.45 \mathrm{psi} / \mathrm{ft})$ in the east and southeast to underpressured values less than $0.25 \mathrm{psi} / \mathrm{ft}(5.7 \mathrm{kPa} / \mathrm{m})$ in the west. Maps of the four younger hydrogeologic units-Permian, Virgilian, Missourian, and Desmoinesian (Figure 17A-D)—display areas of underpressure in southeastern Colorado, southwestern Kansas, and the Oklahoma panhandle. The Permian map (Figure 17A) shows an isoline of $5.7 \mathrm{kPa} / \mathrm{m}(0.25 \mathrm{psi} / \mathrm{ft})$ that borders the underpressured Panhandle-Hugoton gas field in southwestern Kansas and the Oklahoma panhandle. The pressure: depth ratio is less than $9.0 \mathrm{kPa} / \mathrm{m}(0.40 \mathrm{psi} / \mathrm{ft})$ throughout most of Kansas in Desmoinesian-andolder formations (Figure 17D-F).

The map of pressure:depth ratio in Lower Cretaceous rocks (Figure 18), restricted to the Denver Basin where DSTs are available, shows values ranging between 5.7 and $6.8 \mathrm{kPa} / \mathrm{m}(0.25$ and $0.30 \mathrm{psi} / \mathrm{ft}$ ) throughout the densely drilled area in Colorado and western Nebraska, with values less than $5.7 \mathrm{kPa} / \mathrm{m}(0.25 \mathrm{psi} / \mathrm{ft})$ to the northeast, east, and southeast. The east-to-west increase in pressure:depth ratio in Cretaceous rocks (Figure 18) differs from the general west-to-east increase found in Paleozoic rocks (Figure 17).

In the Wattenberg gas field (designated "WF" in Figure 18), the gas-charged Dakota interval is underpressured. Low water-gas production ratios suggest that the pore space is gas dominated and that water is not the continuous phase, thereby cutting off hydraulic communication to the west, and making any permeability cutoff caused by front range faulting even more effective (Nelson and Santus, 2011). In any case, underpressuring in the Wattenberg field appears to be determined by low hydraulic head that in turn is caused by hydraulic communication with outcrops to the east, an observation first made by Hoeger (1968, p. 247).

There is no obvious correspondence between maps of hydraulic head (Figure 14) and maps of pressure:depth ratio (Figure 17) in Paleozoic 

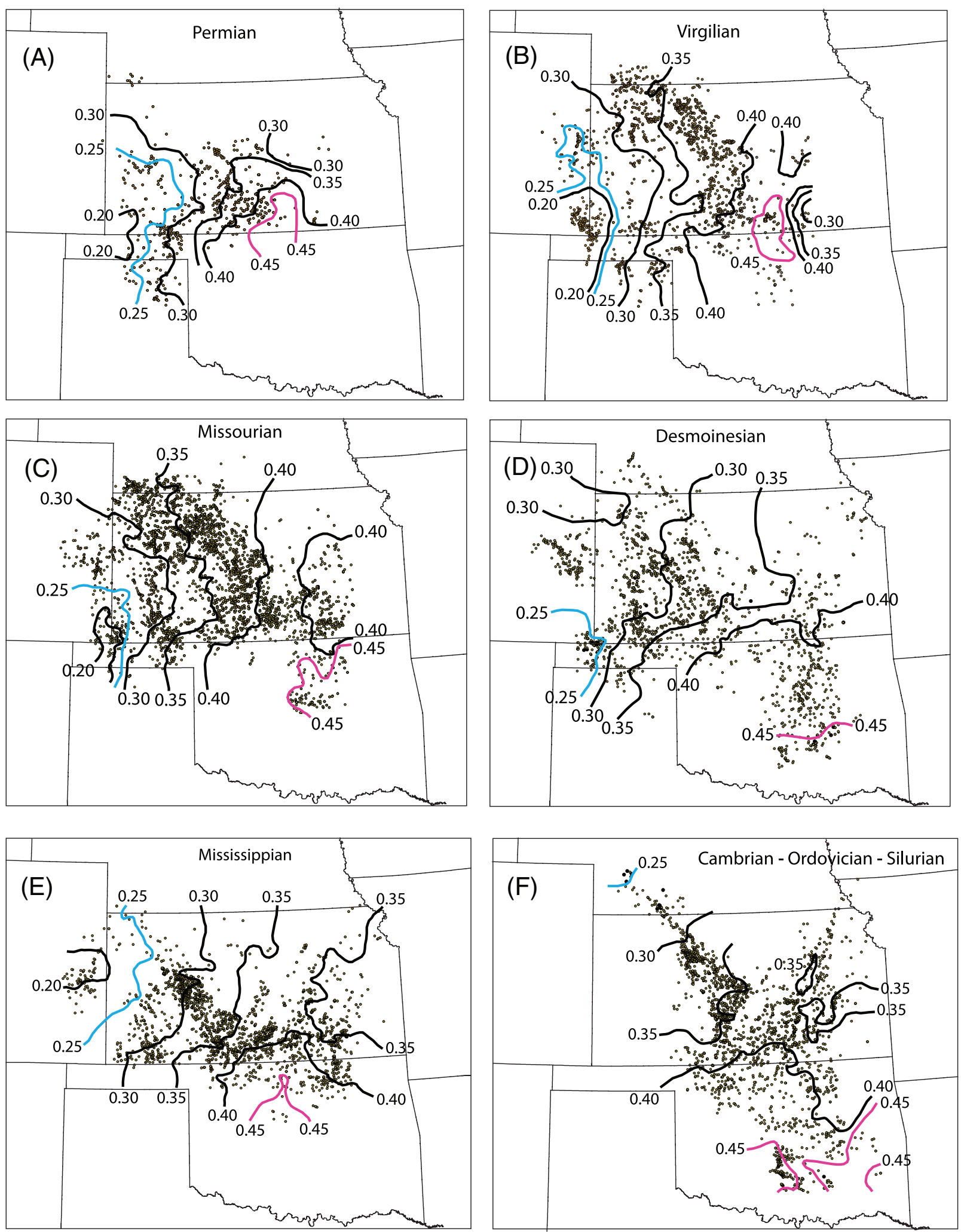

Figure 17. Ratio of pressure to depth in psi/ft for six hydrogeologic units, computed from drill-stem tests (brown dots). Water wells are not shown on these six maps. Cyan contours at $5.7 \mathrm{kPa} / \mathrm{m}(0.25 \mathrm{psi} / \mathrm{ft})$ and magenta contours at $10.2 \mathrm{kPa} / \mathrm{m}(0.45 \mathrm{psi} / \mathrm{ft})$ highlight the areas of lower and higher (near normal) pressure:depth ratio. 


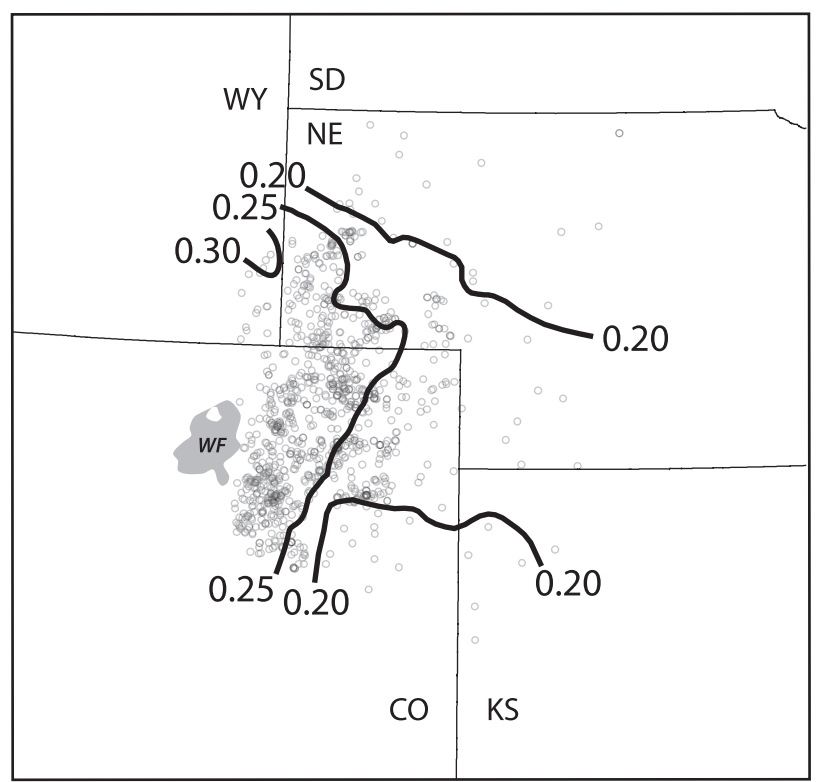

Figure 18. Pressure:depth ratio in psi/ft for the Dakota Group of Early Cretaceous age in the Denver Basin, from selected drillstem tests from wells shown as open circles. WF $=$ Wattenberg gas field.

rocks nor is there a correspondence for the Lower Cretaceous (Figures 15, 18). A recasting of equation 1 reveals the reason for the lack of correspondence. Dividing equation 1 by depth $D$ and rearranging gives an expression for the pressure: depth ratio as

$$
P / D=(\rho g) \times(H-Z) / D=(\rho g) \times(H-Z) /(S-Z)
$$

Equation 2 shows that $P / D$ is a function of the difference between head and test elevation $H-Z$, divided by depth $D=S-Z$. Wherever $H$ is at or near the surface elevation, then $(H-Z) / D$ is nearly $1, P / D=(\rho g)=10.5 \mathrm{kPa} / \mathrm{m}(0.465 \mathrm{psi} / \mathrm{ft})$, and the area is normally pressured. Where $H$ is less than surface elevation, as it is throughout the western part of the study area (Figure 10), then $(H-Z) / D$ is less than one, $P / D$ is some fraction of $(\rho g)=10.5 \mathrm{kPa} / \mathrm{m}(0.465 \mathrm{psi} / \mathrm{ft})$, and the formation is underpressured. Note that depth $D=S-Z$ is the difference between land surface $S$ and test elevation $Z$, as shown in Figure 10, and therefore on a regional scale, $D$ itself is the difference between two surfaces.
Equation 2 can be rewritten in terms of $S-H$

$$
\begin{aligned}
P / D & =(\rho g) \times(1-(S-H)) / D) \\
& =(\rho g) \times(1-(S-H) /(S-Z))
\end{aligned}
$$

As the separation $S-H$ gets larger, the pressure: depth ratio $P / D$ becomes smaller. Hence, maps of separation $S-H$, such as those displayed by Helgesen et al. (1993) and Nelson and Gianoutsos (2014b), are indicative of trends in $P / D$ but do not correlate directly with $P / D$. Equations 2 and 3 show that $P / D$ depends on the dimensionless ratio formed by taking the difference between two surfaces and dividing by the depth, which is the difference between land surface and test elevation. Note that hydraulic head $H$, a measure of the potential energy of the aquifer, is required in either formulation.

For Lower Cretaceous rocks, the lack of resemblance between pressure:depth contours of Figure 18 and the hydraulic head contours of Figure 15 is a result of (1) the deepening DST elevation $Z$ in the Denver Basin, (2) a rise in surface elevation $S$ from the high plains of western Kansas to the Colorado foothills, and (3) hydraulic head $H$ responding to outcrop exposures south and north of the Denver Basin. As explained in the discussion of equations 2 and 3 and Figure 10, a map of pressure:depth ratio $P / D$ responds to the ratio of differences among three surfaces-land elevation $S$, hydraulic head $H$, and test elevation $Z$ - and consequently, a $P / D$ map does not correspond to any one of the three surfaces alone. Thus, although underpressure does occur where $H$ drops below land surface $S$, the topology of a map of underpressure is a complicated function of all three surfaces.

\section{SEQUENCE OF PRESSURE CHANGES AND FLUID MOVEMENT}

The development and present-day topography of underpressure in the Midcontinent is a consequence of the development and topography of three surfaces, as shown explicitly in equations 2 and 3: the land surface (Figure 1), the mean elevation surfaces of the hydrogeologic units (e.g., Figure 2), and the potentiometric surfaces (Figures 14, 15). In this 
section, we place the development of these three surfaces, along with regional pressure changes and fluid migrations, in the context of the geologic history of the Midcontinent.

The structural configurations of the hydrogeologic units (e.g., Figure 2) are a result of (1) formation of the Anadarko Basin during Mississippian through Permian time, (2) formation of the Denver Basin in Late Cretaceous and early Cenozoic time, and (3) rise of the High Plains and Rocky Mountains during Cenozoic time.

Oil and gas were generated during Pennsylvanian and Permian time and migrated from the deep Anadarko Basin in southern Oklahoma as far north as central Kansas, funneled by local structures (Higley, 2014b). Generation and migration of oil and gas in the Denver Basin occurred during the Laramide orogeny in the Late Cretaceous and early Cenozoic.

In the Anadarko Basin, overpressure developed during expulsion of hydrocarbons, then later retreated to the south although a substantial overpressured volume remains today. The overpressured volume is now bordered on its northern and western flanks by underpressured conditions. In the Denver Basin, it is likely, but unconfirmed, that overpressure developed during generation and expulsion, as evidenced by the present-day moderate overpressure of the Codell Sandstone Member of the Carlile Shale and Niobrara Formation overlying the Dakota Group.

Deposition of Permian evaporites and mudstones provided hydraulic isolation of Permian and older units from the land surface. Subsequent dissolution of Permian salts created highly saline brines forming a plume penetrating all Paleozoic strata in central Kansas and Oklahoma. The onset of salt dissolution and its duration are unknown.

Deposition of Cretaceous shales and other lowpermeability units isolated the permeable Dakota Group from the land surface.

Downcutting and erosion during late Cenozoic time exposed geologic units in eastern Kansas and Oklahoma in an east-to-west, oldest-to-youngest progression, thereby allowing equilibration of water pressure to atmospheric pressure. East-west tilting of the land surface resulted from uplift of the High Plains and Rocky Mountains. Uplift occurred episodically during Cenozoic time, with no consensus regarding the relative amount of uplift during different epochs. Thrusting at the Rocky Mountain front created thin bands of outcrop with faulted offsets that may restrict the amount of recharge to confined Paleozoic and Cretaceous aquifers. Together, tilting of the land surface and pressure equilibration at the eastern outcrops combined to establish the potentiometric surfaces well below land surface (Figures 14, 15), thereby creating present-day underpressure.

As underpressure developed, gas migrated northward from the Panhandle field of Texas and Oklahoma, filling the Hugoton gas field of southwestern Kansas and causing expansion of other gas accumulations beyond trap spillpoints with subsequent remigration (Sorenson, 2005). Undoubtedly, other gas accumulations also expanded and migrated into the underpressured areas, particularly on the Las Animas arch where some of the lowest pressure:depth ratios are located.

\section{SUMMARY AND CONCLUSIONS}

Four critical factors related to topographic, geologic, and hydrologic features are important for the creation and preservation of underpressure present in the Midcontinent: (1) eastern outcrops are exposed at a low elevation relative to the rest of the system (Figures 1, 3, 4, 16), (2) surface topography rises away from the down-gradient outcrop in the east (Figures 3, 16), (3) low permeability layers isolate the deep confined aquifer from the water table (Permian evaporites in Figures 8 and 9 and Pierre Shale in Figures 4 and 15 ), and (4) restricted recharge in the west is due to limited surface exposures and faulting.

Outcrop control of potentiometric surfaces is shown by the maps of Figures 14 and 15, with water well and outcrop locations showing the general area in which each hydrogeologic group has equilibrated with atmospheric pressure. On the six Paleozoic potentiometric surfaces, head is lowest in eastern Kansas and northeastern Oklahoma and increases to the west (Figure 14). The Permian potentiometric low of less than $366 \mathrm{~m}(1200 \mathrm{ft})$ lies west of the 305-m (1000-ft) land-surface contour in northeastern 
Kansas (Figure 14A). For Virgilian and older hydrogeologic units, the lows in hydraulic head lie in southeastern Kansas and northeastern Oklahoma where land-surface elevation is less than $305 \mathrm{~m}$ (1000 ft) (Figure 14B-D).

The Lower Cretaceous map also displays hydraulic head increasing westward from an eastern low, but the pattern is more complex because the Dakota Group crops out in a broad arc. The low in hydraulic head is less than $366 \mathrm{~m}$ (1200 ft) in eastern Nebraska and western Iowa. Hydraulic head in the Denver Basin appears linked to outcrop control with upgradient outcrops to the south and downgradient outcrops to the east and north (Figure 15). It appears likely that most flow is west to east along the belts of water wells, with little recharge into the Denver Basin from the south or north. Lack of outcrop exposure in eastern South Dakota produced an artesian aquifer, rather than an underpressured aquifer as seen in other parts of the Midcontinent.

At any given location (e.g., central Kansas), the head $H$ of each hydrogeologic unit is greater than that of the underlying older unit, as expected from the exposure of older Permian and Pennsylvanian units at progressively lower elevations. The decrease in $H$ with age holds true even for Mississippian and Cambrian to Silurian units, for which potentiometric lows are apparently governed by topography of the Arkansas River Valley in eastern Oklahoma rather than their respective outcrops on the Ozark Plateaus. The general downward gradient of $H$ throughout the Midcontinent can result in downward vertical flow from one hydrogeologic unit to the one below. The downward gradient is likely to have contributed to the vertical distribution of the high-salinity plume.

From eastern Oklahoma to eastern Colorado, $H$ increases by $600 \mathrm{ft}$ (183 m) in Mississippian rocks, a much smaller increase than $1600 \mathrm{ft}(488 \mathrm{~m})$ in Desmoinesian rocks (Figure 14). The comparatively low overall hydraulic gradient and lack of a steep gradient in western Kansas and eastern Colorado observed in Mississippian rocks is attributed to relatively high permeability acquired by erosion and deep weathering of the Mississippian surface during a prolonged depositional hiatus. The contrasting high gradient in Permian to Desmoinesian units may be attributed to a reduction in permeability due to a facies change across the Las Animas arch. Low west-east $H$ gradients in all six confined Paleozoic systems indicate that regional meteoric recharge is now minimal.

\section{REFERENCES CITED}

Anderson, N. L., J. F. Hopkins, A. Martinez, R. W. Knapp, P. A. Macfarlane, W. L. Watney, and R. A. Black, 1994, Dissolution of bedded rock salt; a seismic profile across the active eastern margin of the Hutchinson Salt Member, central Kansas: Computers and Geosciences, v. 20, no. 5, p. 889-903, doi:10.1016/0098-3004(94)90120-1.

Bachu, S., 1995, Flow of variable-density formation water in deep sloping aquifers: Review of methods of representation with case studies: Journal of Hydrology, v. 164, no. 1-4, p. 19-38, doi:10.1016/0022-1694(94)02578-Y.

Banner, J. L., G. J. Wasserburg, P. F. Dobson, A. B. Carpenter, and C. H. Moore, 1989, Isotopic and trace element constraints on the origin and evolution of saline groundwaters from central Missouri: Geochimica et Cosmochimica Acta, v. 53, no. 2, p. 383-398, doi:10.1016/0016-7037(89) 90390-6.

Belitz, K., and J. D. Bredehoeft, 1988, Hydrodynamics of Denver Basin: Explanation of subnormal fluid pressures: AAPG Bulletin, v. 72, no. 11, p. 1334-1359.

Bingham, R. H., and D. L. Bergman, 1980, Reconnaissance of the water resources of the Enid Quadrangle, north-central Oklahoma: Oklahoma Geological Survey Hydrologic Atlas 7, 4 sheets.

Bredehoeft, J. D., C. E. Neuzil, and P. C. D. Milly, 1983, Regional flow in the Dakota aquifer: A study of the role of confining layers: U.S. Geological Survey Water-Supply Paper 2237, 45 p.

Breit, G. N., 2002, Produced waters database: U.S. Geological Survey, accessed March 13, 2013, http://energy.cr.usgs .gov/prov/prodwat/index.htm.

Clair, J. R., and R. W. Volk, 1968, Pre-Permian Paleozoic rocks of the Las Animas Arch-A new oil province: Mountain Geologist, v. 5, no. 3, p. 95-108.

Gianoutsos, N. J., and P. H. Nelson, 2013, Creating potentiometric surfaces from combined water well and oil well data in the Midcontinent of the United States: Geological Society of America 2013 Annual Meeting, Denver, Colorado, October 27-30, 2013, Paper 301-10, accessed August 18, 2015, https://gsa.confex.com/gsa/2013AM /webprogram/Paper226579.html.

Helgesen, J. O., R. B. Leonard, and R. J. Wolf, 1993, Hydrology of the Great Plains aquifer system in Nebraska, Colorado, Kansas, and adjacent areas: U.S. Geological Survey Professional Paper 1414-E, 80 p., 10 pls.

Higley, D. K., 2014a, Thermal maturation of petroleum source rocks in the Anadarko basin province, Colorado, Kansas, Oklahoma, and Texas, in D. K. Higley, comp., Petroleum systems and assessment of undiscovered oil and gas in the Anadarko Basin Province, Colorado, Kansas, Oklahoma, and Texas-USGS Province 58: U.S. Geological Survey 
Digital Data Series 69-EE, chapter 3, 53 p., doi:10.3133 /ds69EE.

Higley, D. K., 2014b, Petroleum systems and assessment of undiscovered oil and gas in the Anadarko basin province, Colorado, Kansas, Oklahoma, and Texas-Mississippian through Permian assessment units, in D. K. Higley, comp., Petroleum systems and assessment of undiscovered oil and gas in the Anadarko Basin Province, Colorado, Kansas, Oklahoma, and Texas-USGS Province 58: U.S. Geological Survey Digital Data Series 69-EE, chapter 7, 60 p., doi:10.3133/ds69EE.

Hoeger, R. L., 1968, Hydrodynamic study of the western Denver Basin, Colorado, in J. C. Hollister and R. J. Weimer, eds., Geophysical and geological studies of the relationships between the Denver earthquakes and the Rocky Mountain Arsenal well: Colorado School of Mines Quarterly: Golden, Colorado, Colorado School of Mines, v. 63, p. 235-251.

Hubbert, M. K., 1956, Darcy's law and the field equations of the flow of underground fluids: Transactions of the American Institute of Mining, Metallurgical, and Petroleum Engineering, v. 207, p. 222-239.

IHS Energy, 2012, U.S. production and well data: Englewood, Colorado, database available from IHS Energy, 15 Inverness Way East, Englewood, Colorado 80112.

Jorgensen, D. G., J. O. Helgesen, and J. L. Imes, 1993, Regional aquifers in Kansas, Nebraska, and parts of Arkansas, Colorado, Missouri, New Mexico, Oklahoma, South Dakota, Texas, and Wyoming-geohydrologic framework: U.S. Geological Survey Professional Paper 1414-B, 72 p., accessed August 18, 2015, http://pubs.er.usgs.gov /publication/pp1414B.

Kharaka, Y. K., and J. S. Hanor, 2013, Deep fluids in sedimentary basins, in K. K. Turekian and H. D. Holland, eds., Treatise on geochemistry, 2nd edition: Amsterdam, The Netherlands, Elsevier Science, chapter 5.16, 45 p.

Macfarlane, P. A., 1995, The effect of river valleys and the upper Cretaceous aquitard on regional flow in the Dakota aquifer in the central Great Plains of Kansas and southeastern Colorado: Kansas Geological Survey Bulletin 238, p. 11-30.

Macfarlane, P. A., 2010, Temporal variability in the quality of produced water from wells tapping the Ozark Aquifer of southeast Kansas: Current Research in Earth Sciences, Kansas Geological Survey Bulletin 258, part 3, 35 p., accessed August 29, 2013, http://www.kgs.ku.edu /Current/2010/Macfarlane/index.html.

Mallory, W. W., 1972, Regional synthesis of the Pennsylvanian system, in W. W. Mallory, ed., Geologic atlas of the Rocky Mountain region: Denver, Colorado, Rocky Mountain Association of Geologists, p. 111-127.

Marcher, M. V., and R. H. Bingham, 1971, Reconnaissance of the water resources of the Tulsa Quadrangle, northeastern Oklahoma: Oklahoma Geological Survey Hydrologic Atlas 2, 4 sheets.

Merewether, E. A., 1987, Oil and gas plays of the Las Animas Arch, southeastern Colorado: U.S. Geological Survey Open-File Report 87-450D, 22 p., accessed August 18, 2015, http://pubs.er.usgs.gov/publication/ofr87450D.
Merriam, D. F., 1963, The geologic history of Kansas: Kansas Geological Survey Bulletin 162, 317 p.

Miser, H. D., 1954, Geological map of the state of Oklahoma: Reston, Virginia, U.S. Geological Survey, 1 sheet.

Morton, R. B., 1980, Reconnaissance of the water resources of the Woodward Quadrangle, northwestern Oklahoma: Oklahoma Geological Survey Hydrologic Atlas 8, 4 sheets.

Mugel, D. N., and W. P. Pratt, 1991, Lithologic cross sections of Phanerozoic rocks in the northern Midcontinent, U.S.A.: U.S. Geological Survey Map MF-1835-G, pamphlet, 7 sheets.

Musgrove, M., and J. L. Banner, 1993, Regional ground-water mixing and the origin of saline fluids: Midcontinent, United States: Science, v. 259, no. 5103, p. 1877-1882, doi:10.1126/science.259.5103.1877.

Nelson, P. H., and N. J. Gianoutsos, 2014a, Present-day overpressure and paleopressure indicators in the greater Anadarko Basin, Oklahoma, Texas, Kansas, and Colorado, in D. K. Higley, comp., Petroleum systems and assessment of undiscovered oil and gas in the Anadarko Basin Province, Colorado, Kansas, Oklahoma, and Texas-USGS Province 58: U.S. Geological Survey Digital Data Series 69-EE, chapter 8, 28 p., doi:10.3133/ds69EE.

Nelson, P. H., and N. J. Gianoutsos, 2014b, Potentiometric surfaces for seven stratigraphic units and an explanation for underpressure in the greater Anadarko Basin, Oklahoma, Texas, Kansas, and Colorado, in D. K. Higley, comp., Petroleum systems and assessment of undiscovered oil and gas in the Anadarko Basin Province, Colorado, Kansas, Oklahoma, and Texas-USGS Province 58: U.S. Geological Survey Digital Data Series 69-EE, chapter 9, 24 p., doi:10.3133/ds69EE.

Nelson, P. H., N. J. Gianoutsos, and L. O. Anna, 2013, Outcrop control of basin-scale underpressure in the Raton Basin, Colorado and New Mexico: The Mountain Geologist, v. 50, no. 2, p. 37-63.

Nelson, P. H., and S. L. Santus, 2011, Gas, water, and oil production from Wattenberg field in the Denver Basin, Colorado: U.S. Geological Survey Open-File Report 2011-1175, 23 p., 2 pls, accessed August 18, 2015, http://pubs.usgs.gov /of/2011/1175/.

Osborn, N. I., S. J. Smith, and C. H. Seger, 2013, Hydrogeology, distribution, and volume of saline groundwater in the southern Midcontinent and adjacent areas of the United States: U.S. Geological Survey Scientific Investigations Report 2013-5017, 58 p., doi:10.3133/sir20135017.

Rascoe, B., Jr., 1978, Late Paleozoic structural evolution-The Las Animas arch, in J. D. Pruit and P. E. Coffin, eds., Energy resources of the Denver Basin: Denver, Colorado, Rocky Mountain Association of Geologists, p. 113-127.

Rascoe, B., Jr., and D. L. Baars, 1972, Permian system, in W. W. Mallory, ed., Geologic atlas of the Rocky Mountain region: Denver, Colorado, Rocky Mountain Association of Geologists, p. 143-165.

Schruben, P. G., R. E. Arndt, and W. J. Bawiec, 1997, Geology of the Conterminous United States at 1:2,500,000 scale-A digital representation of the 1974 P. B. King and H. M. Beikman Map: USGS Digital Data Series 11, release 2, accessed June 7, 2012, http://pubs.usgs.gov/dds/dds11/. 
Sims, P. K., 1985, Precambrian basement map of the northern Midcontinent, U.S.A.: U.S. Geological Survey Open-File Report 85-604, accessed August 18, 2015, http://pubs.er .usgs.gov/publication/ofr85604.

Sorenson, R. P., 2005, A dynamic model for the Permian Panhandle and Hugoton fields, western Anadarko Basin: AAPG Bulletin, v. 89, no. 7, p. 921-938, doi:10.1306 /03010504045.

Thornton, M. M., and A. M. Wilson, 2007, Topography-driven flow versus buoyancy-driven flow in the U.S. Midcontinent: Implications for the residence time of brines: Geofluids, v. 7, no. 1, p. 69-78, doi:10.1111/j.1468-8123.2006.00164.x.

US Geological Survey, 2012, National water information system: Web interface, accessed April 11, 2013, http://waterdata .usgs.gov/nwis/.

Ward, P. E., 1963, Geology and ground-water features of salt springs, seeps, and plains in the Arkansas and Red River Basins of western Oklahoma and adjacent parts of Kansas and Texas: U.S. Geological Survey Open-File Report 63-132, 94 p., accessed August 18, 2015, http://pubs.er.usgs .gov/publication/ofr63132.
Watney, W. L., E. K. Franseen, A. P. Byrnes, and S. E. Nissen, 2008, Evaluating structural controls on the formation and properties of Carboniferous carbonate reservoirs in the northern Midcontinent, U.S.A., in J. Lukasik and J. A. Simo, eds., Controls on carbonate platform and reef development: SEPM Special Publication 89, $21 \mathrm{p}$.

Watney, W. L., W. J. Guy, and A. P. Byrnes, 2001, Characterization of the Mississippian chat in south-central Kansas: AAPG Bulletin, v. 85, no. 1, p. 85-113.

Watney, W. L., S. E. Nissen, S. Bhattacharya, and D. Young, 2003, Evaluation of the role of evaporite karst in the Hutchinson, Kansas gas explosions, January 17 and 18, 2001, in K. S. Johnson and J. T. Neal, eds., Evaporite karst and engineering/environmental problems in the United States: Oklahoma Geological Survey Circular 109, p. 119-147.

Wolf, A. V., G. B. Morden, and P. G. Prentiss, 1973, Concentrative properties of aqueous solutions: Conversion tables, in R. C. Weast, ed., Handbook of chemistry and physics: New York, CRC Press, p. D2192-D2234. 